\title{
Traditional Uses of Plants in the Tolfa-Cerite-Manziate Area (Central Italy)
}

Paolo Maria Guarrera ${ }^{1}$, Valentina Savo ${ }^{2,3^{*}}$, and Giulia Caneva ${ }^{3}$

Author Addresses: ${ }^{1}$ Istituto Centrale per la Demoetnoantropologia, Ministero dei Beni e delle Attività Culturali e del Turismo, Piazza Marconi 8-10, 00144 Rome, Italy. ${ }^{2}$ Hakai Institute, Simon Fraser University, 8888 University Drive, Burnaby, BC V5A 1S6, Canada. ${ }^{3}$ Department of Science, University Roma Tre, Viale Marconi 446, 00146 Rome, Italy.

*Corresponding author: vsavo@sfu.ca

Received: October 17, 2014

Published: September 2, 2015

Volume: $6(1): 119-161$

(C) 2015 Society of Ethnobiology

Abstract: Traditional knowledge of local plant uses is rapidly fading away, especially in rural Mediterranean areas. We carried out ethnobotanical research in 2010-2011 in order to investigate the local knowledge of wild plants in the TolfaCerite-Manziate area of Italy (Latium, district of Rome). We carried out a total of 45 semi-structured interviews with farmers, herders, and fishers. Here, a simple diachronic comparison is made between the current study and a previous one conducted in some of the villages of the study area to highlight potential losses of traditional knowledge of local plants. We documented a total of 102 plant species, belonging to 48 families, along with their uses (excluding food uses). We also reported some non-plant based remedies that were primarily used in veterinary medicine. Some plant uses, especially for making handicrafts, have not been reported previously (e.g., those of Celtis australis L. Cannabaceae, Betula pendula Roth Betulaceae). Many plant uses are no longer remembered in the area, which indicates a loss of local ethnobotanical knowledge.

Keywords: Ethnobiology, Folk remedies, Cultural erosion, Latium

\section{Introduction}

Local, traditional, or indigenous knowledge of plant uses is rapidly disappearing in many areas of the world (Cox 2000). This is especially evident in several European countries, where such knowledge evolved over centuries of human use of the environment (Pardo-de-Santayana et al. 2010). Despite this recent cultural erosion, ethnobotanical research in Europe is still limited in comparison with other regions, especially for studies exploring plant uses other than medicine and food.

Many ethnobotanical studies have been carried out in Italy over the last few decades (Guarrera 2006). The majority of these studies focused on medicinal plant uses. Despite the fact that researchers have hypothesized contamination of local ethnobotanical knowledge either with ancient medicinal treatises or neoteric knowledge (Leonti et al. 2009; Pardo-deSantayana et al. 2010), many studies continue to highlight interesting and novel plant uses.

In this ethnobiological study, we focus our attention on the Tolfa-Cerite-Manziate area. The territory has been inhabited over time by protoEtruscans, Etruscans (seventh century BC) and then by Romans (third century BC) (Vander Poppen 2008). It belonged to the Papal States from the eighth century to the nineteenth century. The area has always had a rural character despite its proximity to the city of Rome and its suburbs (Salvati and Sabbi 2011). Today, this rural area is famous for cattle breeds (e.g., the Maremmana) but local farmers also raise horses, sheep, and other animals.

Over time, people in the study area have developed a complex corpus of ethnobiological knowledge and traditions. This knowledge has only been explored in the ethnobiological literature once by P. M. Guarrera and M. Chiavoni over a period spanning from 1980 to 1990 (Guarrera 1994). Despite the fact that only a part of the territory was surveyed (Tolfa Mountains and Canale Monterano) and documented uses were limited to medicinal and food plants, the study by Guarrera (1994) suggested the presence of a rich body of ethnobiological knowledge.

The current study is nested within a broader research project aimed at exploring ethnobotanical knowledge in Italy (e.g., Caneva et al. 2013; Guarrera 2006) and has two aims: 


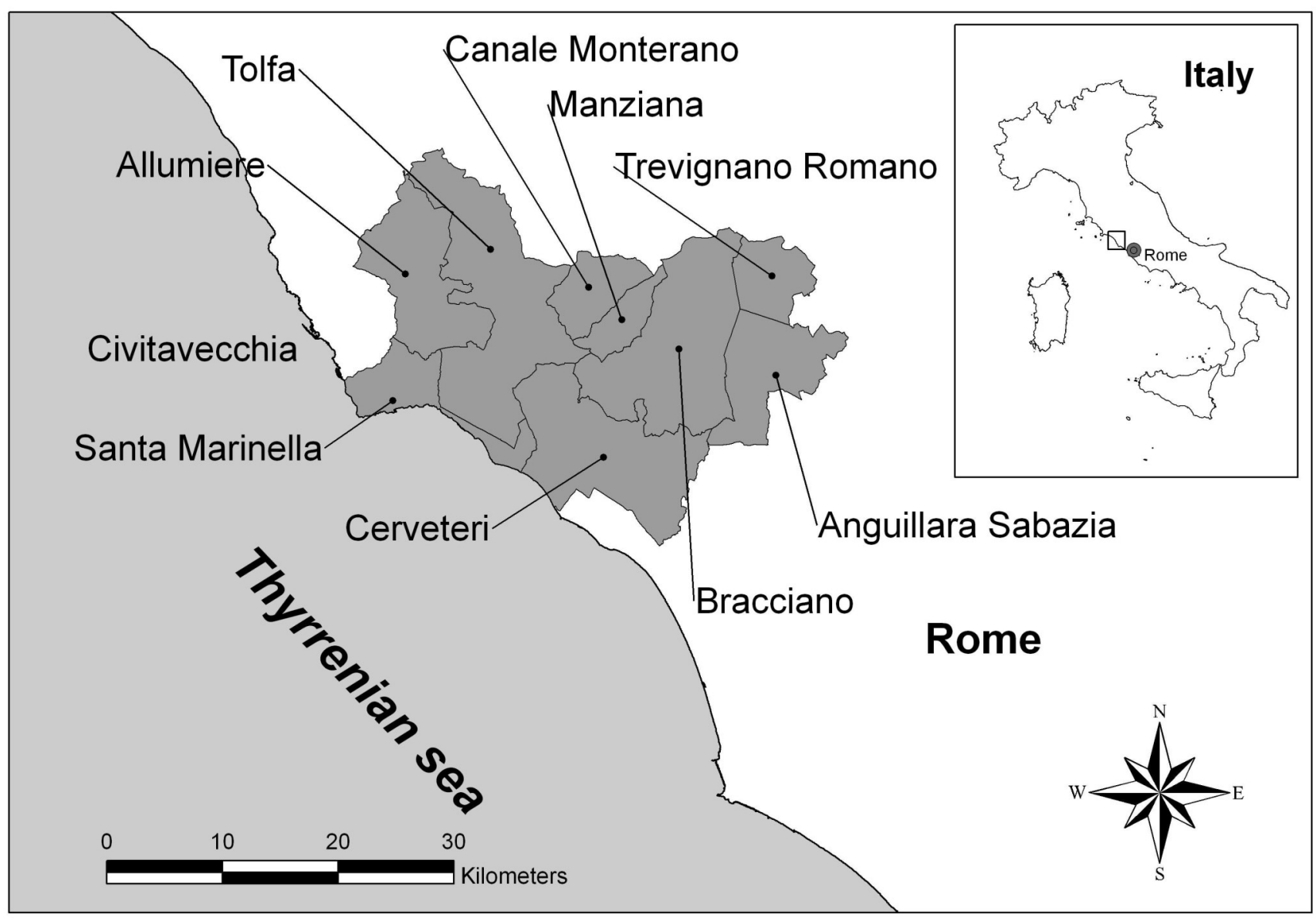

Figure 1. Geographical position of the study area with names of the municipalities.

To document information on current ethnobotanical knowledge of people in the Tolfa-CeriteManziate area (including plant uses that are often neglected such as those related to handicraft making, domestic and agro-pastoral uses as well as ritual use).

To compare the data collected in this study with those reported in Guarrera (1994), which dates back to the 1990 s and to other studies in the Latium region in order to identify loss of knowledge and novelty in plant uses. Extensive data on food plants are reported in a separate article.

\section{Study area}

The investigated area covers the northern part of the Nuts-3 prefecture of Rome (Latium, central Italy) with a total surface of $556 \mathrm{~km}^{2}$ (Figure 1). The area is located between longitude $11^{\circ} 44^{\prime}-12^{\circ} 11^{\prime}$ and latitude $41^{\circ} 55^{\prime}-42^{\circ} 14^{\prime}$. As part of an ancient volcanic system, the area is bounded by mountains (Monti Cimini and
Monti Sabatini) and by the Tyrrhenian Sea.

The landscape is featured by a mosaic of plains, hills and low mountains (the highest elevation of the Tolfa Mountains is the Monte delle Grazie, $616 \mathrm{~m}$ a.s.l.). Mountains are partially of volcanic origin and formed by older sedimentary deposits of flyschoids (Angelelli and Faramondi 1995; Devoto and Lombardi 1977). The alluvial plain of the Tiber River constitutes part of the lowlands of the area (Salvati and Sabbi, 2011).

The climate is Mediterranean with some areas at the edge of the temperate belt (Savo et al. 2012). The average long-term (1951-2007) annual rainfall totals $805 \mathrm{~mm}$, while the average annual medium temperature is $15.5^{\circ} \mathrm{C}$ [climate data were obtained from the CRA-CMA (2012)]. However, decreases in precipitation coupled with an increase of temperature have been recorded in recent years (Savo et al. 2012).

The vegetation landscape is characterized by a mosaic of pastures, cultivated land, and woodland. A 
majority of the landscape persists as natural or seminatural habitats (Fanelli et al. 2007), despite the occurrence of fires (especially during the summer) and the relatively high human presence (urban sprawl from the city of Rome). The typical Mediterranean landscape has been preserved in some stands, including meadows with wild Cynara cardunculus L. Asteraceae and grasslands with sulphurous springs. Most of the woodlands are composed of broad-leaf species (e.g., Fagus sylvatica L. Fagaceae, Quercus robur L. Fagaceae, Castanea sativa Mill. Fagaceae), especially on hillsides (Anzalone 1961; Di Pietro 2010; Spada 1977). The area includes many sites of the Natura 2000 network and Sites of Community Importance (SCI) (Habitats Directive'1).

A large part of the study area is covered by scattered towns and villages. Some industrial areas are located in the Southern lowlands close to the city of Rome, while rural areas are more abundant in the Western part of the study area (Salvati and Sabbi, 2011).

\section{Methods}

Ethnobotanical survey and analysis of data

The Tolfa-Cerite-Manziate area includes 9 municipalities: Allumiere, Anguillara Sabazia, Bracciano, Canale Monterano, Cerveteri, Manziana, Santa Marinella, Tolfa, and Trevignano Romano (Figure 1). These municipalities span from the coast to an inland hilly area bordering Bracciano Lake (of volcanic origin).

We collected data on plant uses between 2010 and 2011 through semi-structured interviews without time limits (Bernard 1988). We used a purposive sampling technique (Bernard 1988) by selecting informants among people with a close relationship with the local environment. When approaching a village, we approached elders sitting on benches, people at senior centers, or people working on their land. In some cases information on potential informants was also solicited from local bartenders. Informants were selected among farmers, shepherds (butteri), fishers and housewives (who generally cultivate at least a home garden). During our field surveys, we performed 45 interviews. Each informant was first presented information about the aims of the study and Prior Informed Consent (Rosenthal 2006) was requested verbally before starting the interview. Consent was also requested to conduct interviews using an audio recorder and to photograph plants and eventually handicrafts or herbal preparations. Interviews were conducted following the ISE Code of Ethics (ISE 2006).

Interviews were structured in two parts. The first part of the interview was aimed at collecting personal data on the informants (age, job, place of residence). The second part of the interview was focused on the relationship of the informants with plants and concerning how informants were using plants. Specifically, we recorded data on the vernacular name of the species, the description of uses, and the parts used. We also recorded if informants used fresh or dried plants and if they used plant species in combination with others. In addition, we recorded how mixtures are prepared and doses related to plant uses (especially of medicinal plants). In this paper, we report all plant uses with the exception of food uses (Table 1, Table 2): medicinal, veterinary, handicraft, domestic, ritual uses, games, agro-pastoral, and antiparasitic uses. Plant uses were categorized following the classification suggested in Signorini et al. (2013), with the addition of the category for anti-parasitic uses, which was not considered in that work. We also reported non-plant based uses, which are mostly remedies used in human and veterinary folk medicine (Table 3).

We gathered the plants used and noted by the informants. All the plants that were mentioned were taken into account even if noted by a sole informant. Plant species were identified following the "Flora d'Italia" (Pignatti 1982) with use of updated scientific nomenclature (ThePlantList.org 2014).

The reported plant uses were then qualitatively compared to those reported in a previous study (Guarrera 1994) conducted in a region partially overlapping with the study area. Similar comparisons done in other regions are reported in Di Tizio et al. (2012) and Pieroni et al. (2013). Methods used in this study were similar to those used in the Guarrera (1994) even though that study was mainly focused on medicinal and food plants and was conducted at a different time and in a smaller area. The small set of data did not allow for quantitative analyses so, for this reason, we only performed a qualitative comparison of lists of plant species and plant uses. As an example, the use of $S$. nigra to make blowguns was documented in Guarrera (1994) but it was also reported by informants in the current study. Other plant uses were generally similar, such as the use of olive oil for tending burns in our study and for treating insect bites 


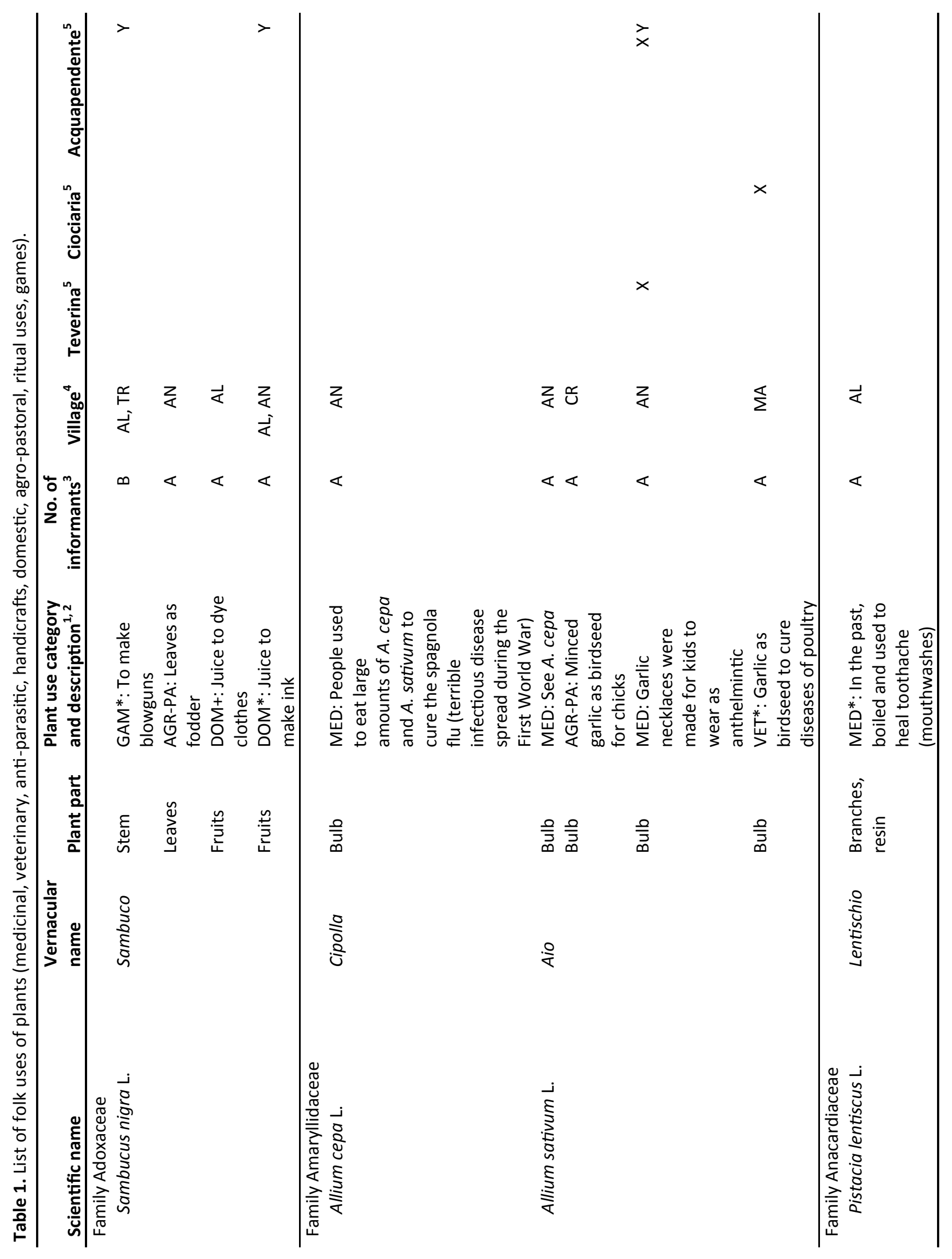

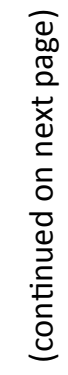









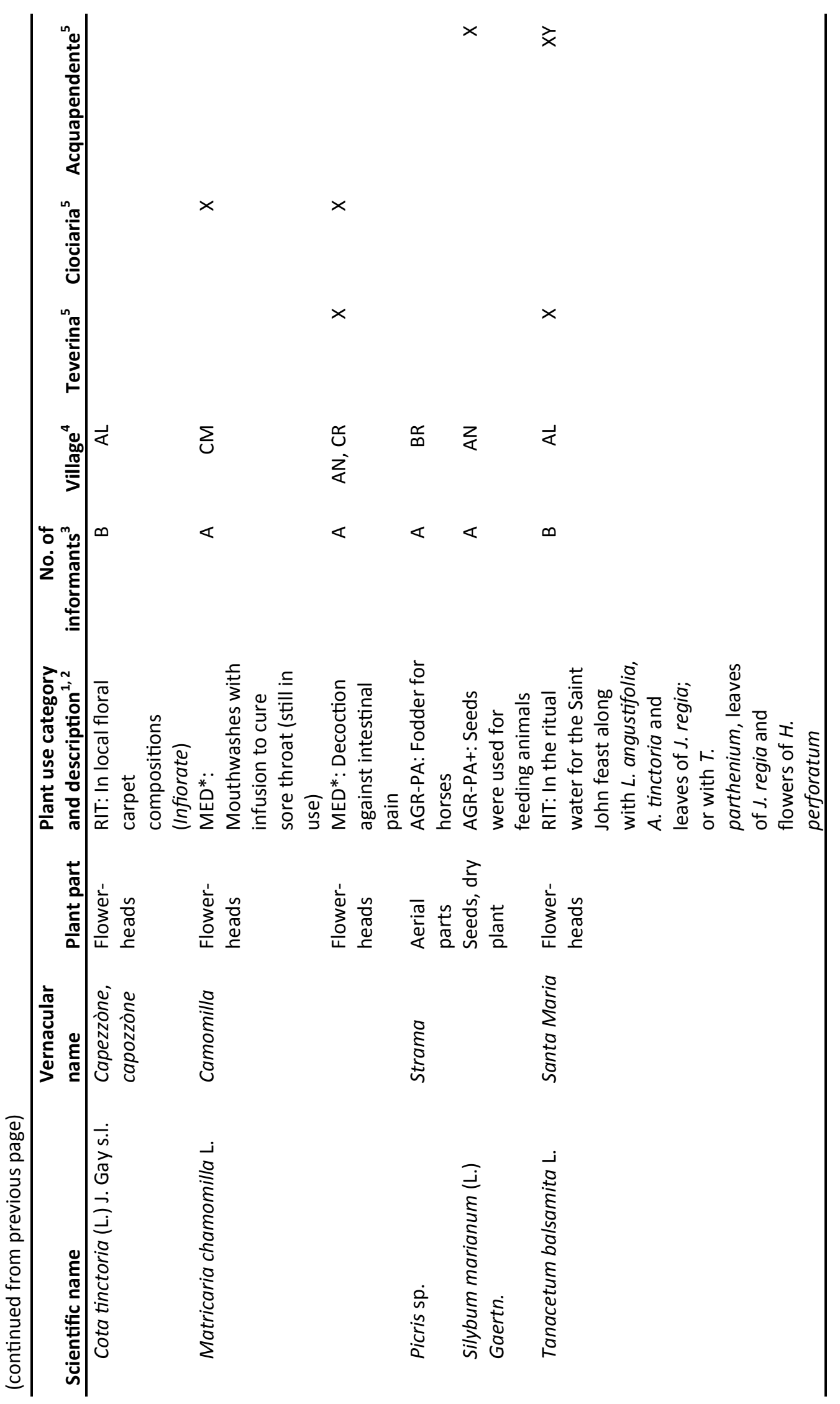




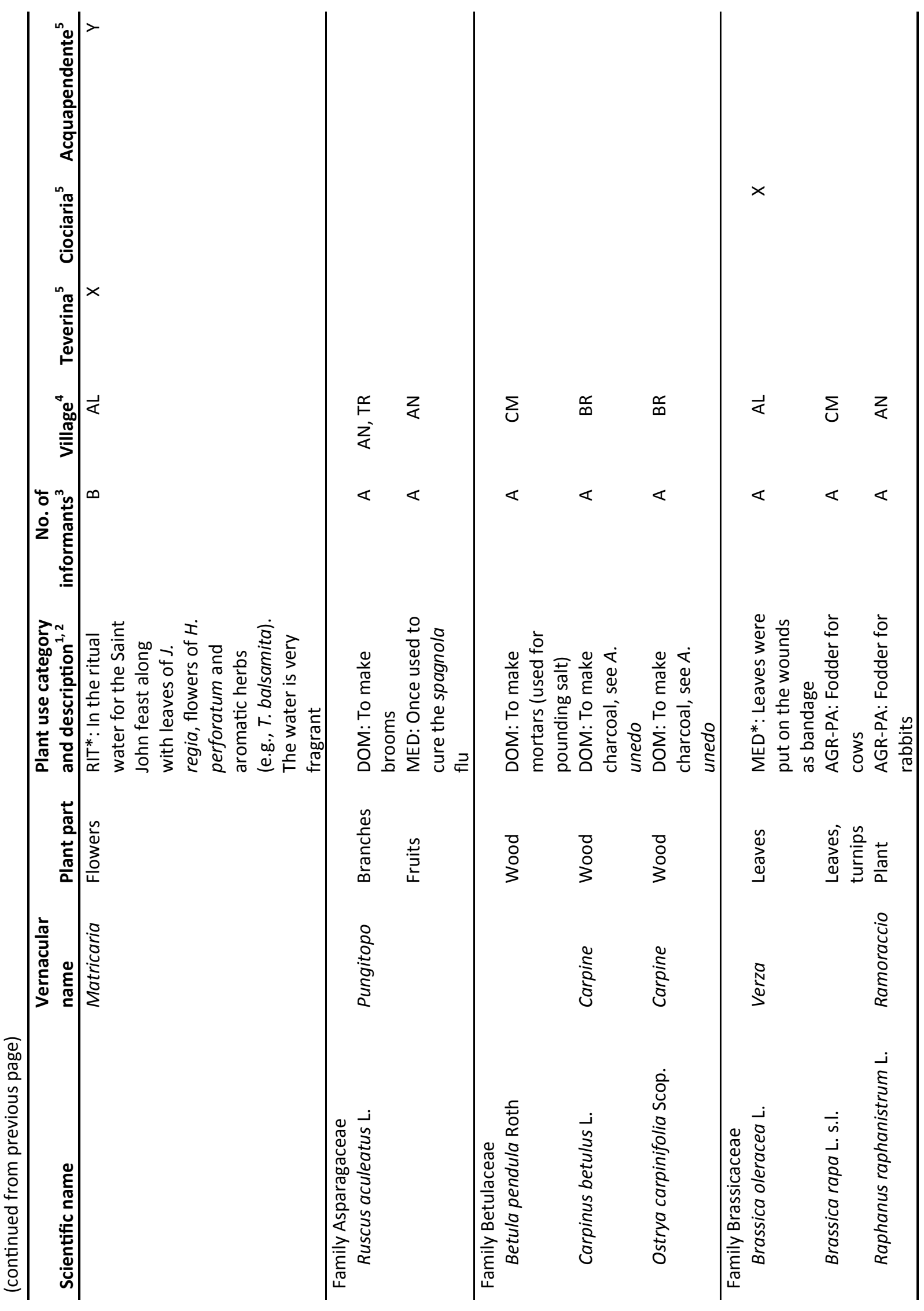

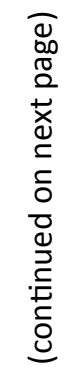




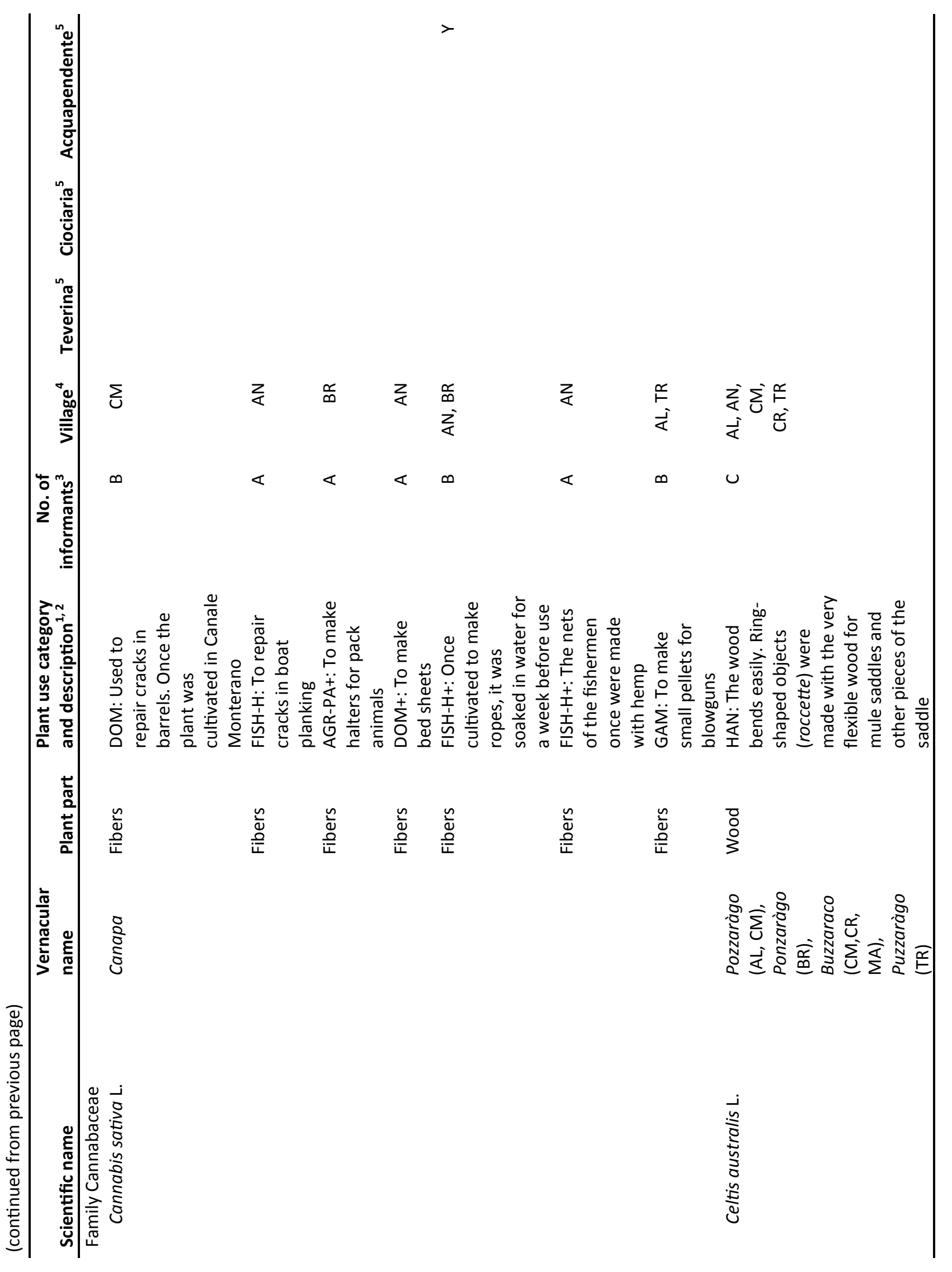

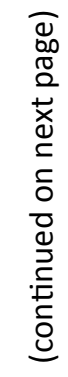




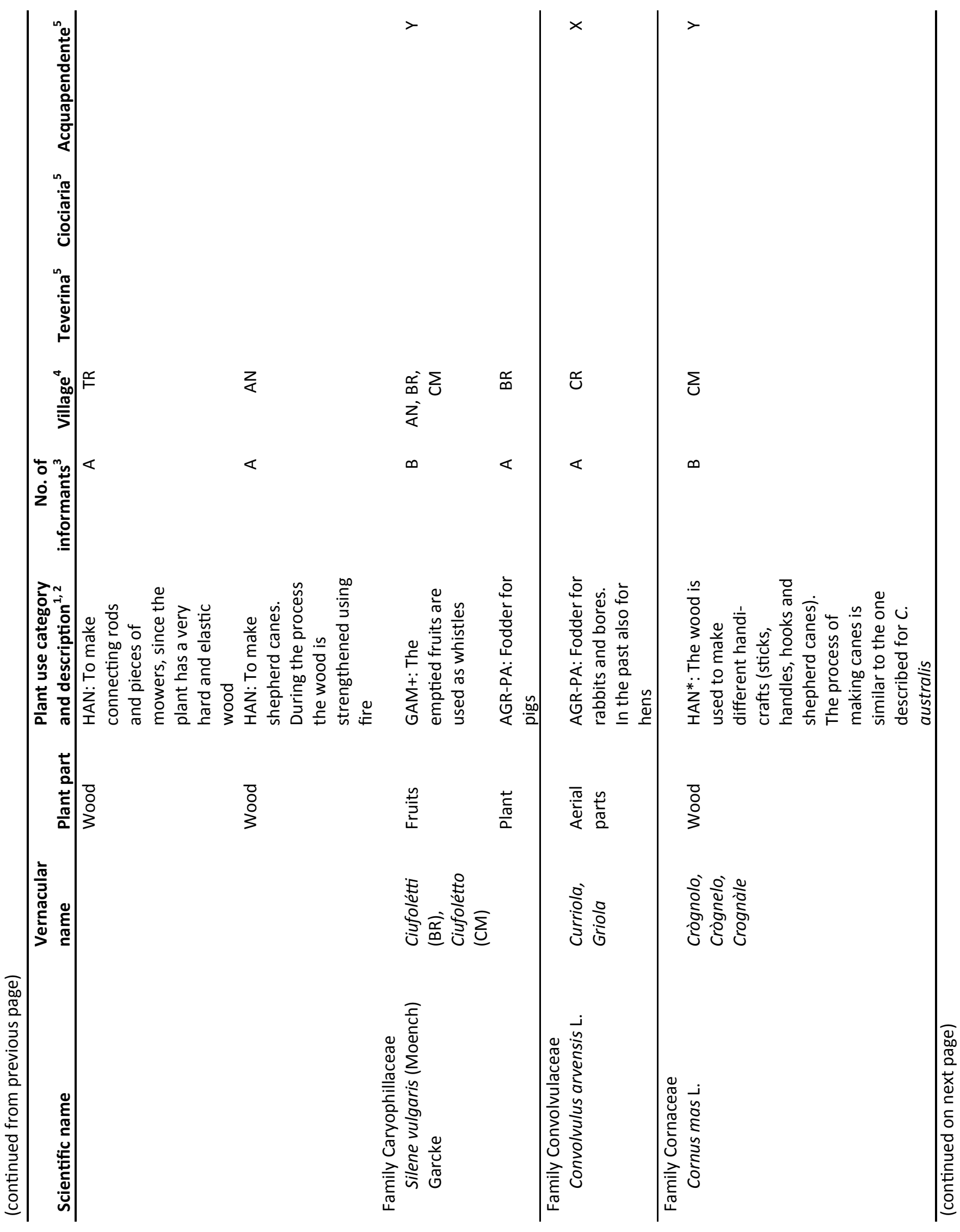


ETHNOBIOLOGY LetTers Research Communication

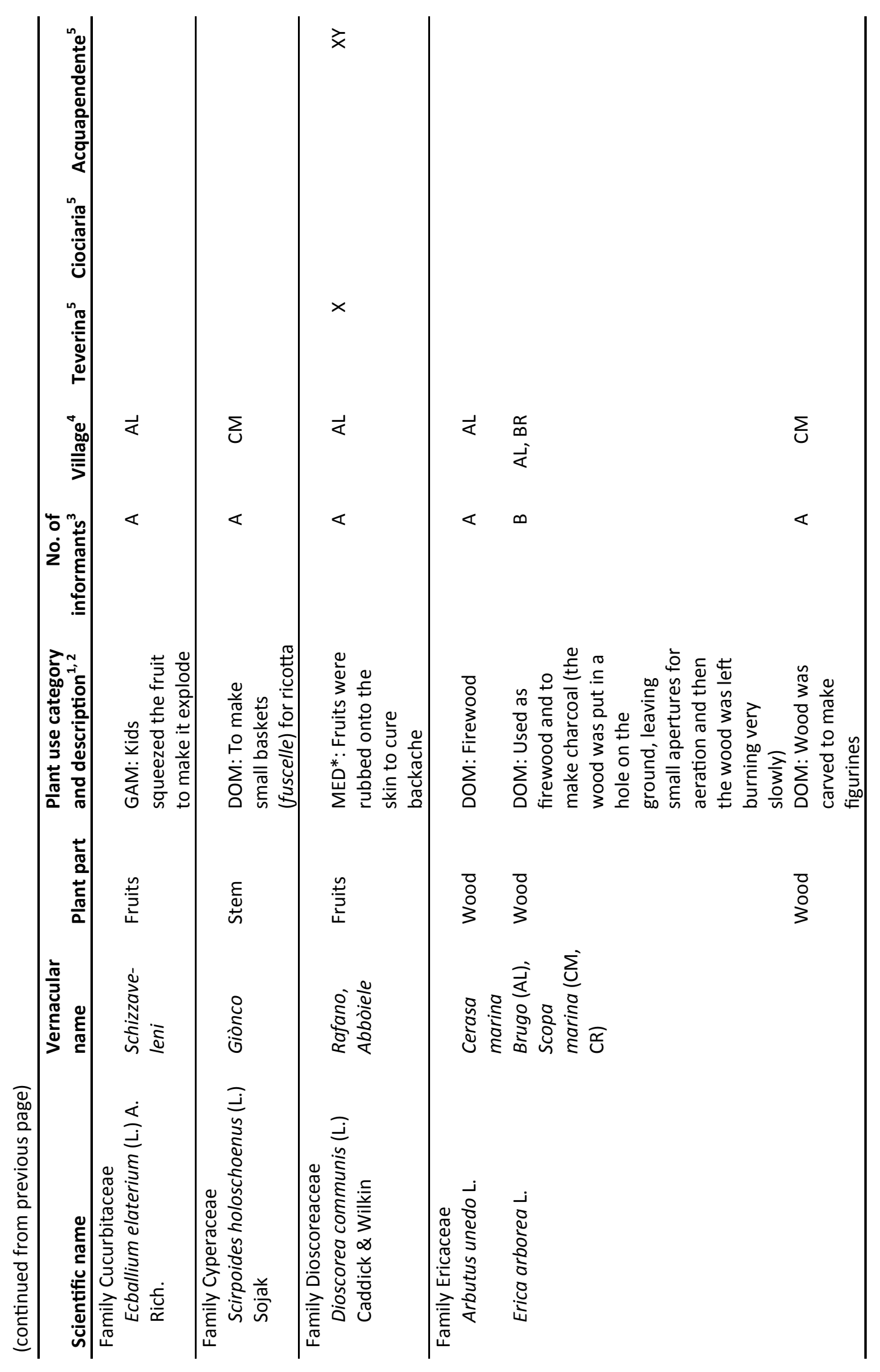









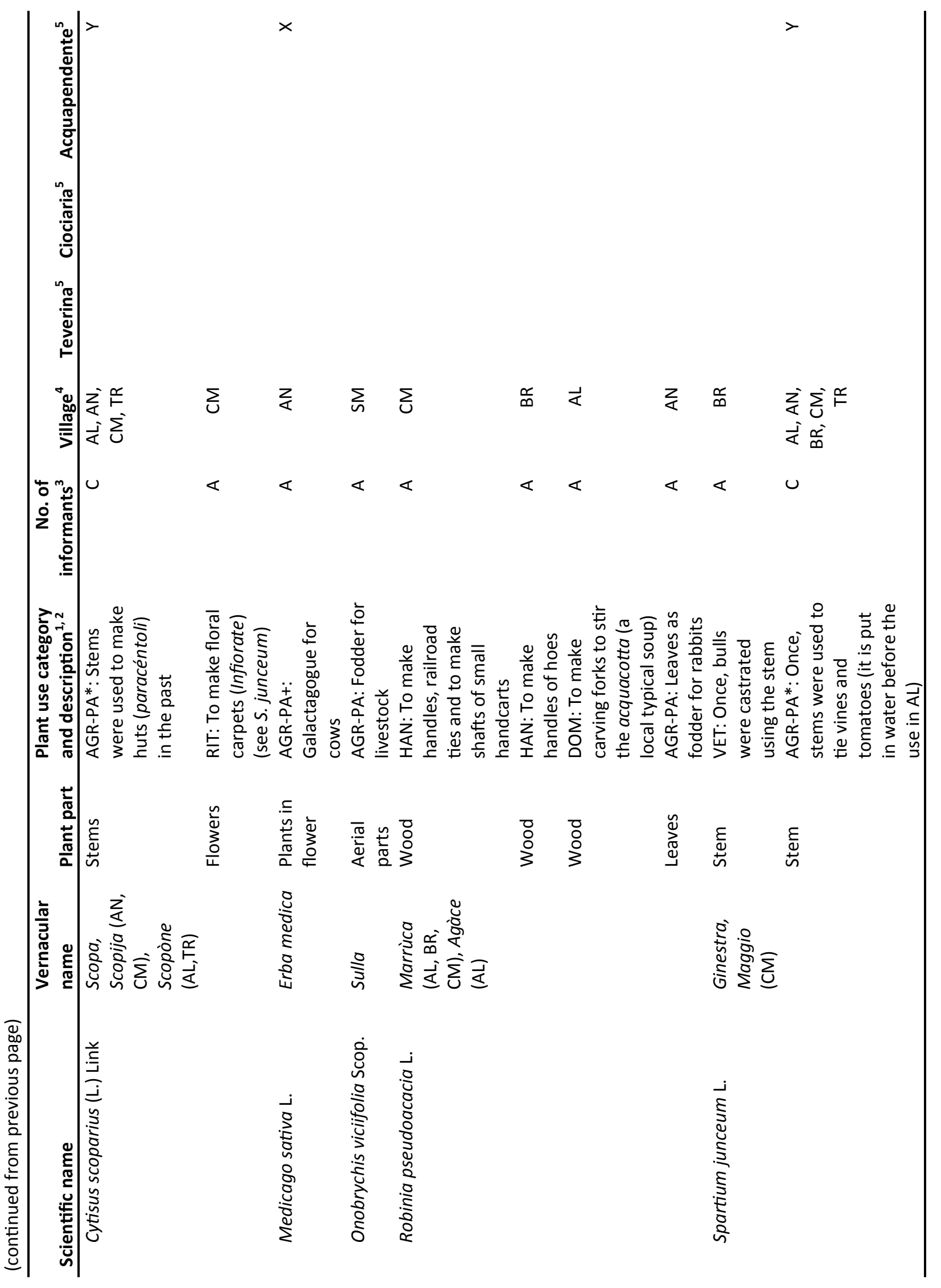














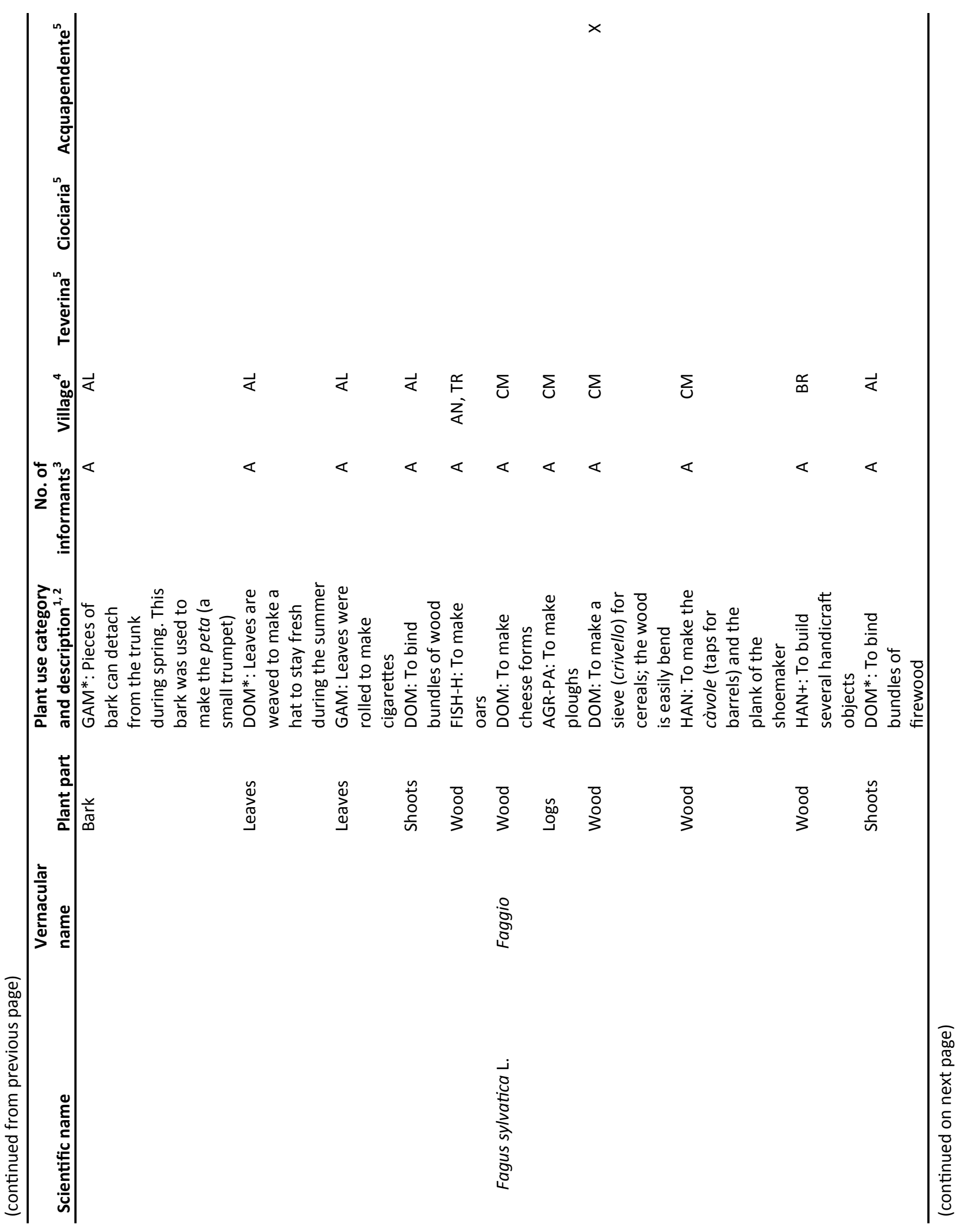




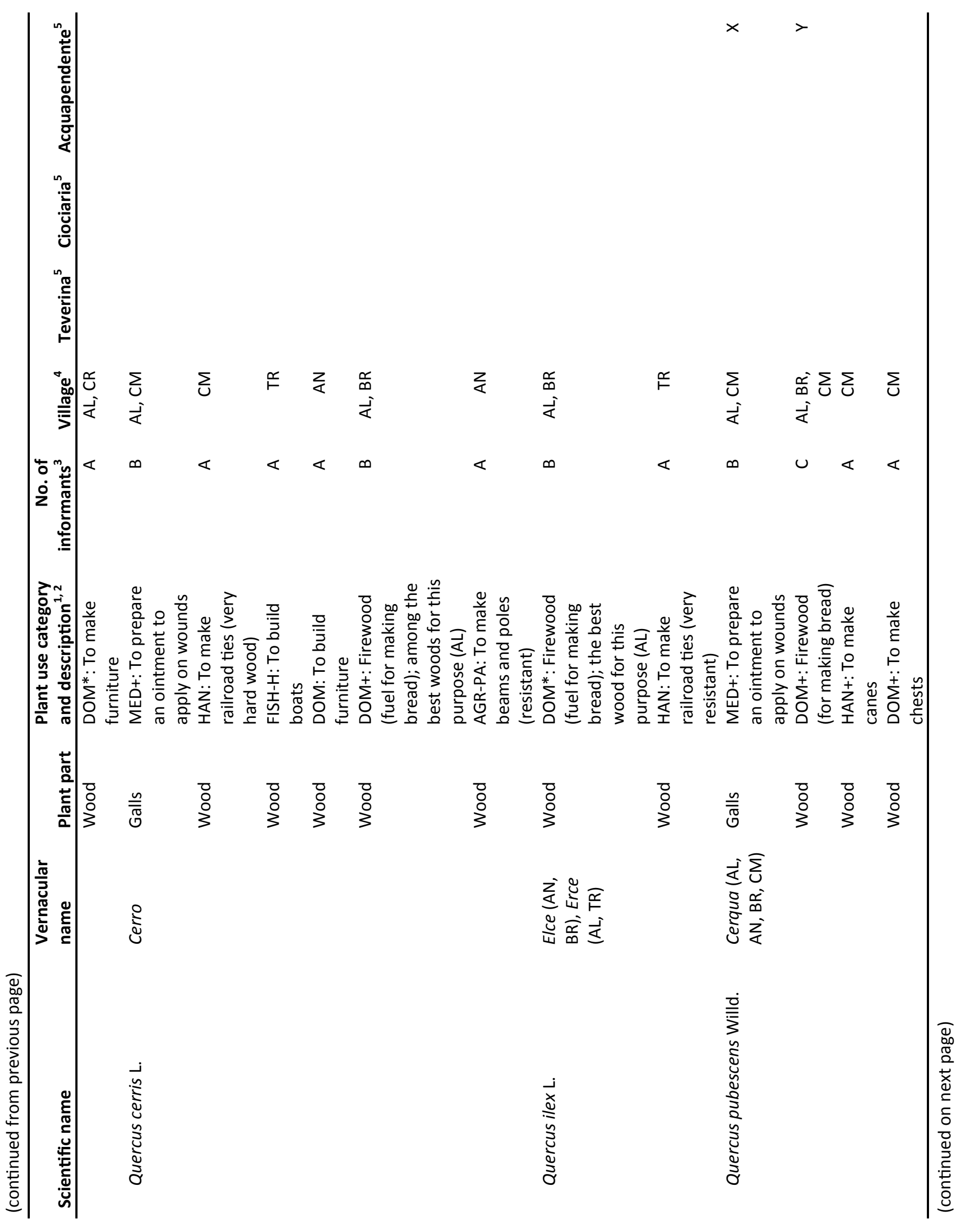




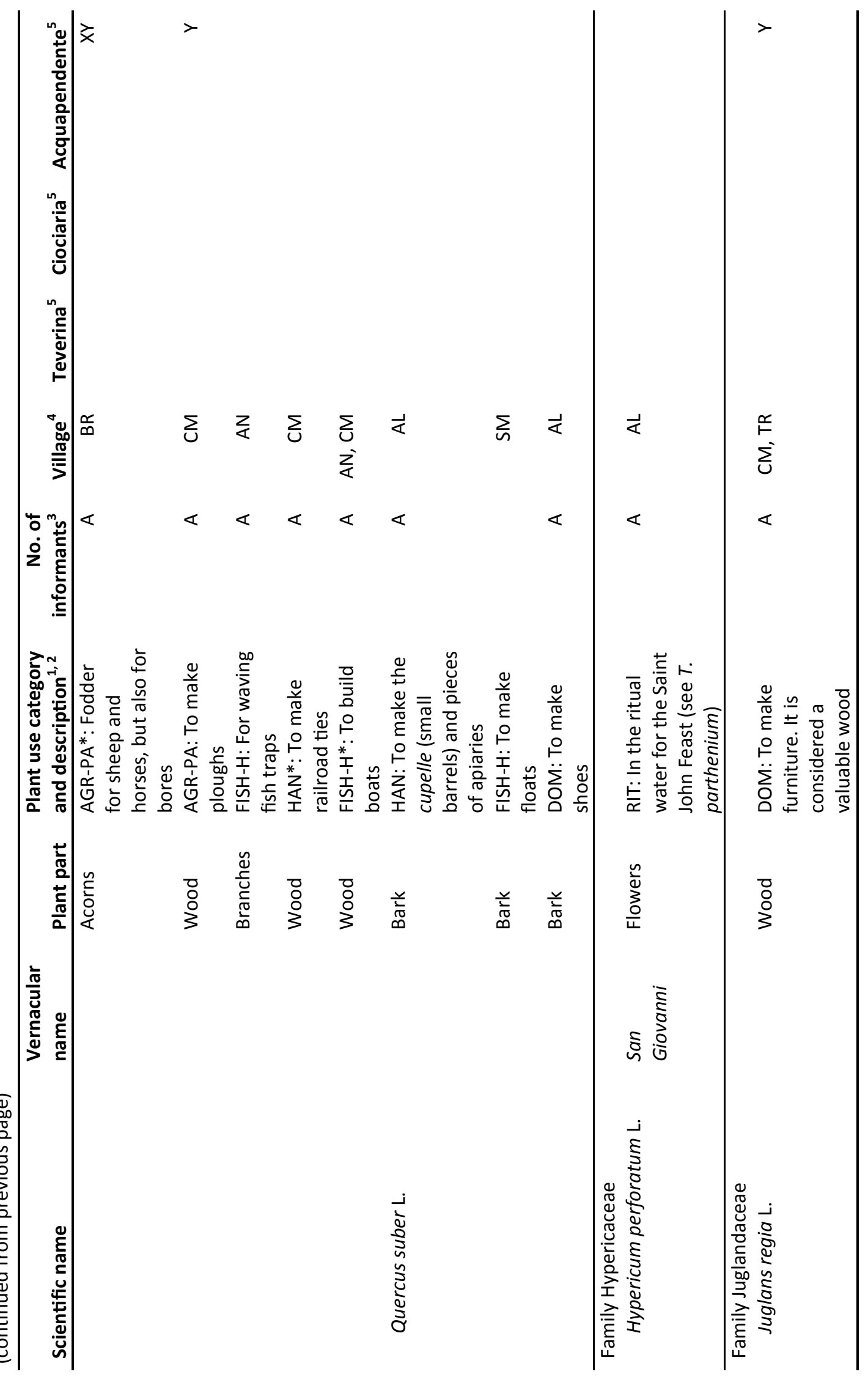


ETHNOBIOLOGY LetTers Research Communication

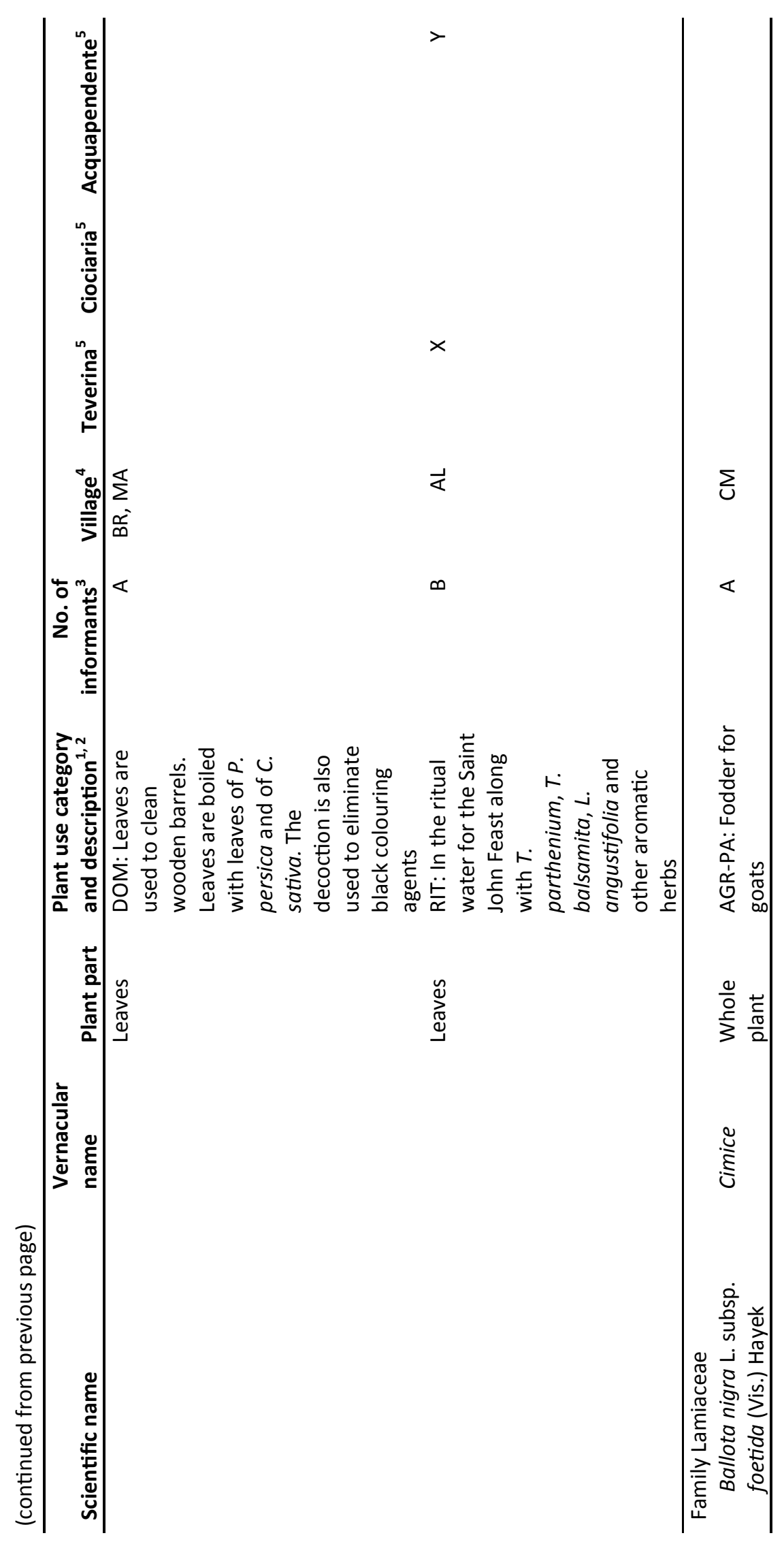




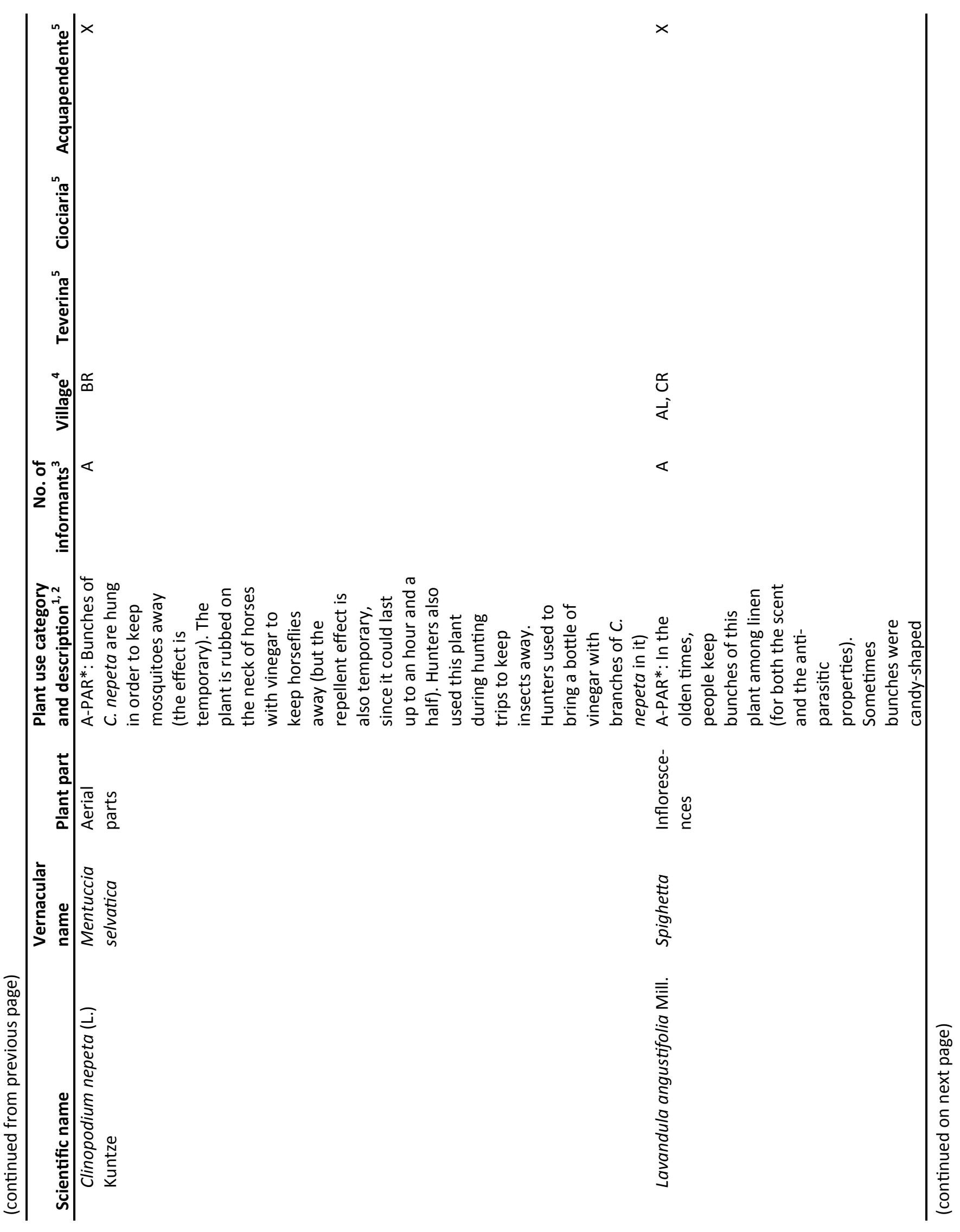

Ethnobiology Letters. 2015. 6(1):119-161. DOI: 10.14237/ebl.6.1.2015.288. 


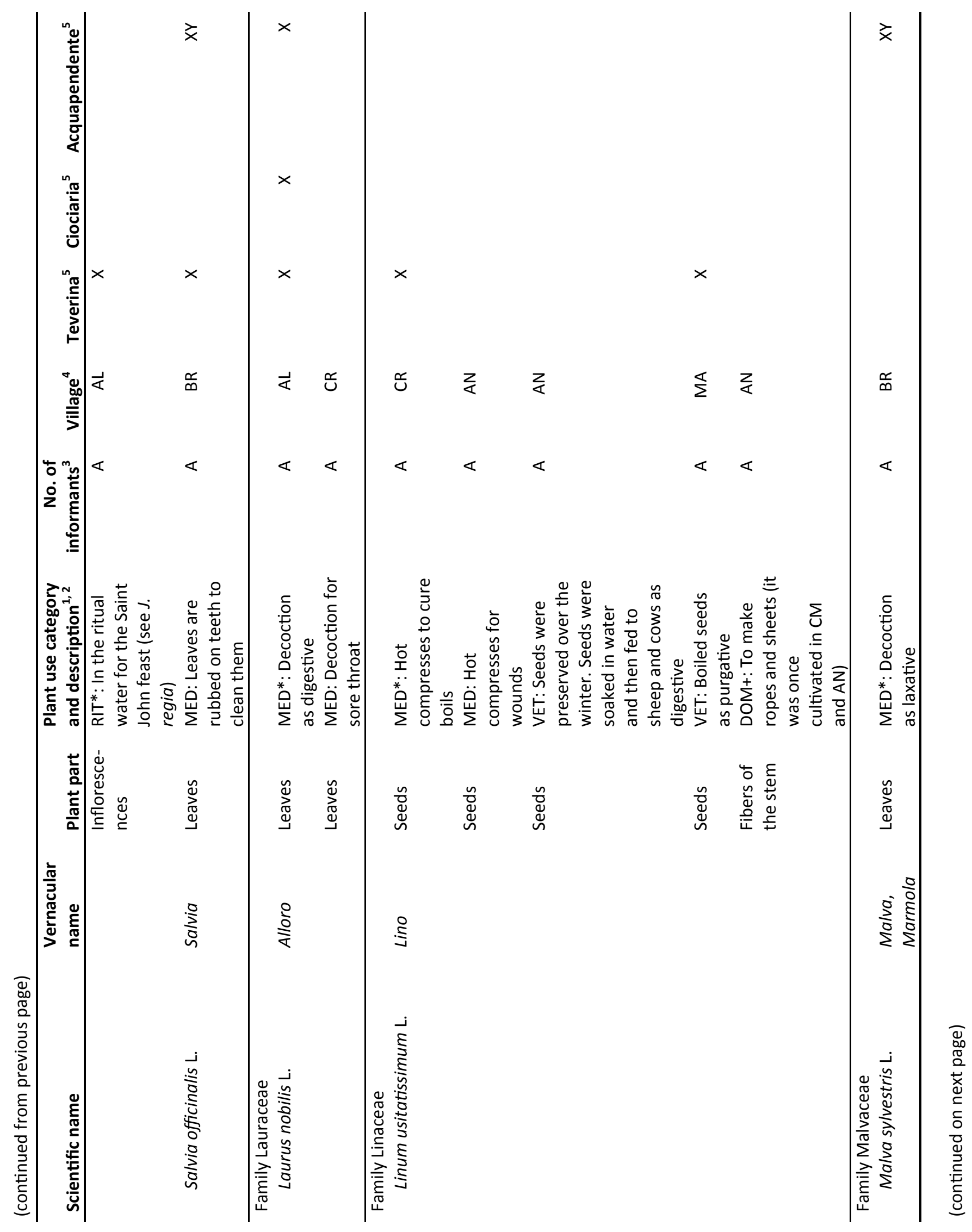




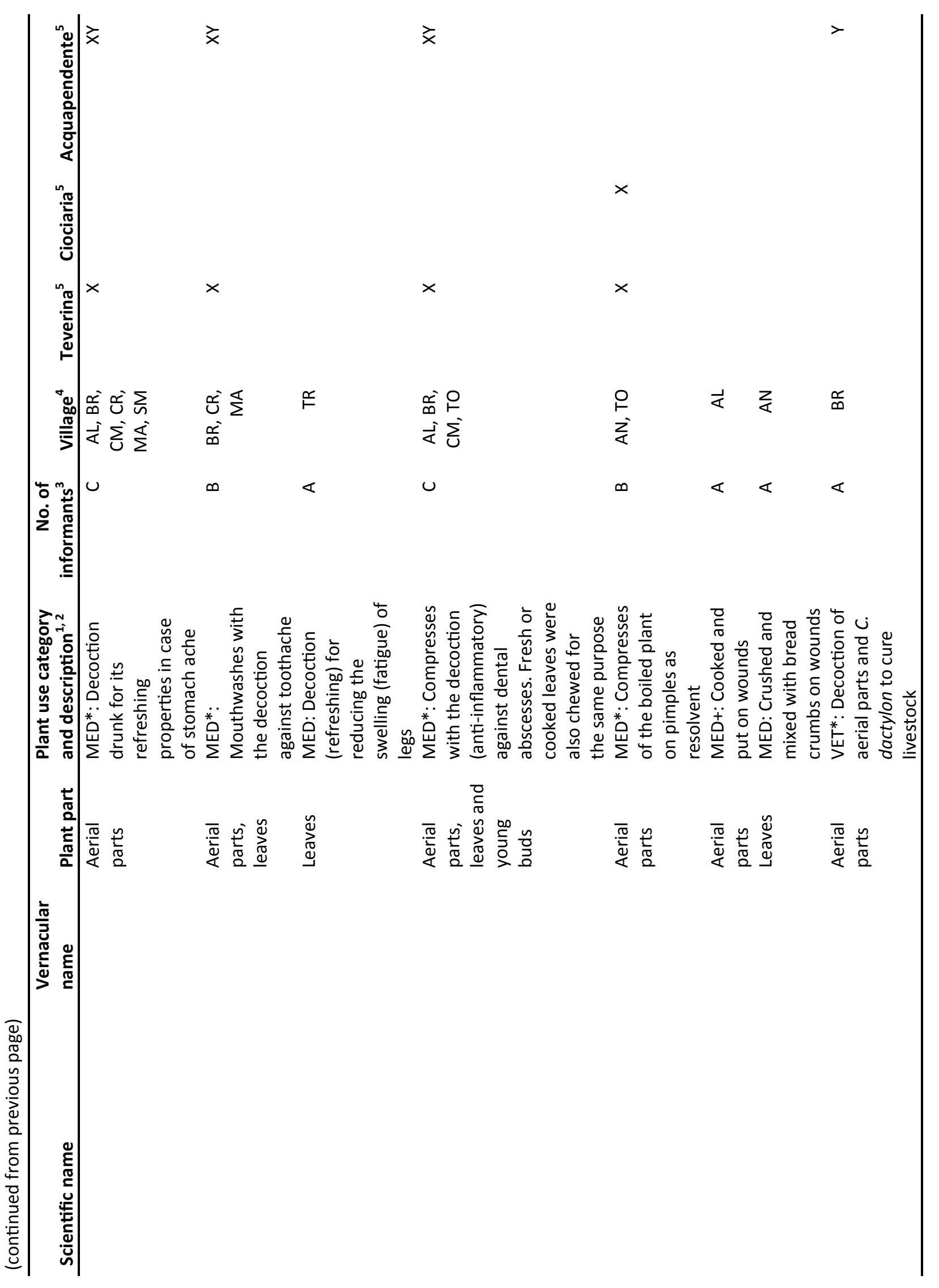


Ethabiology LetTers Research Communication






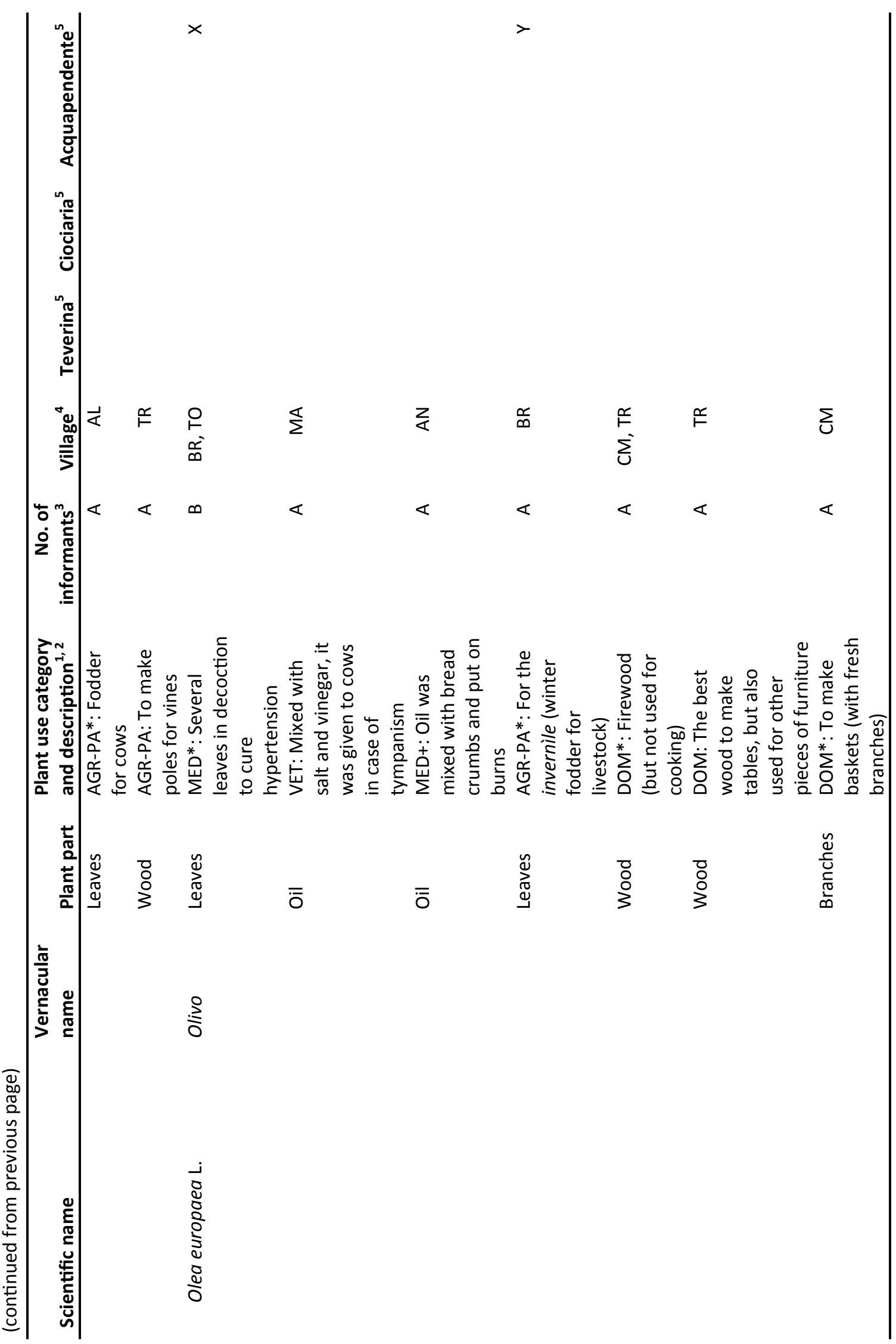




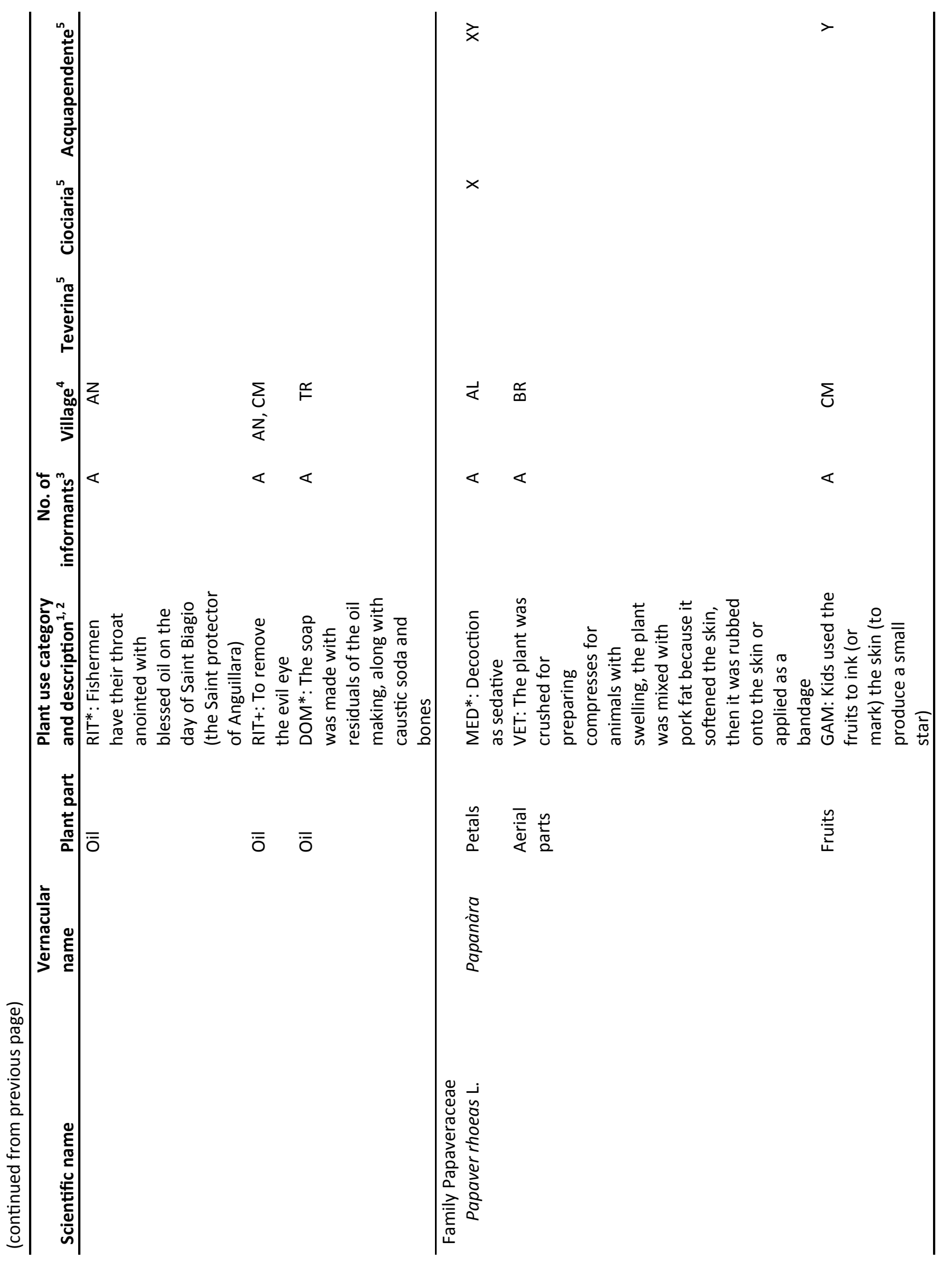






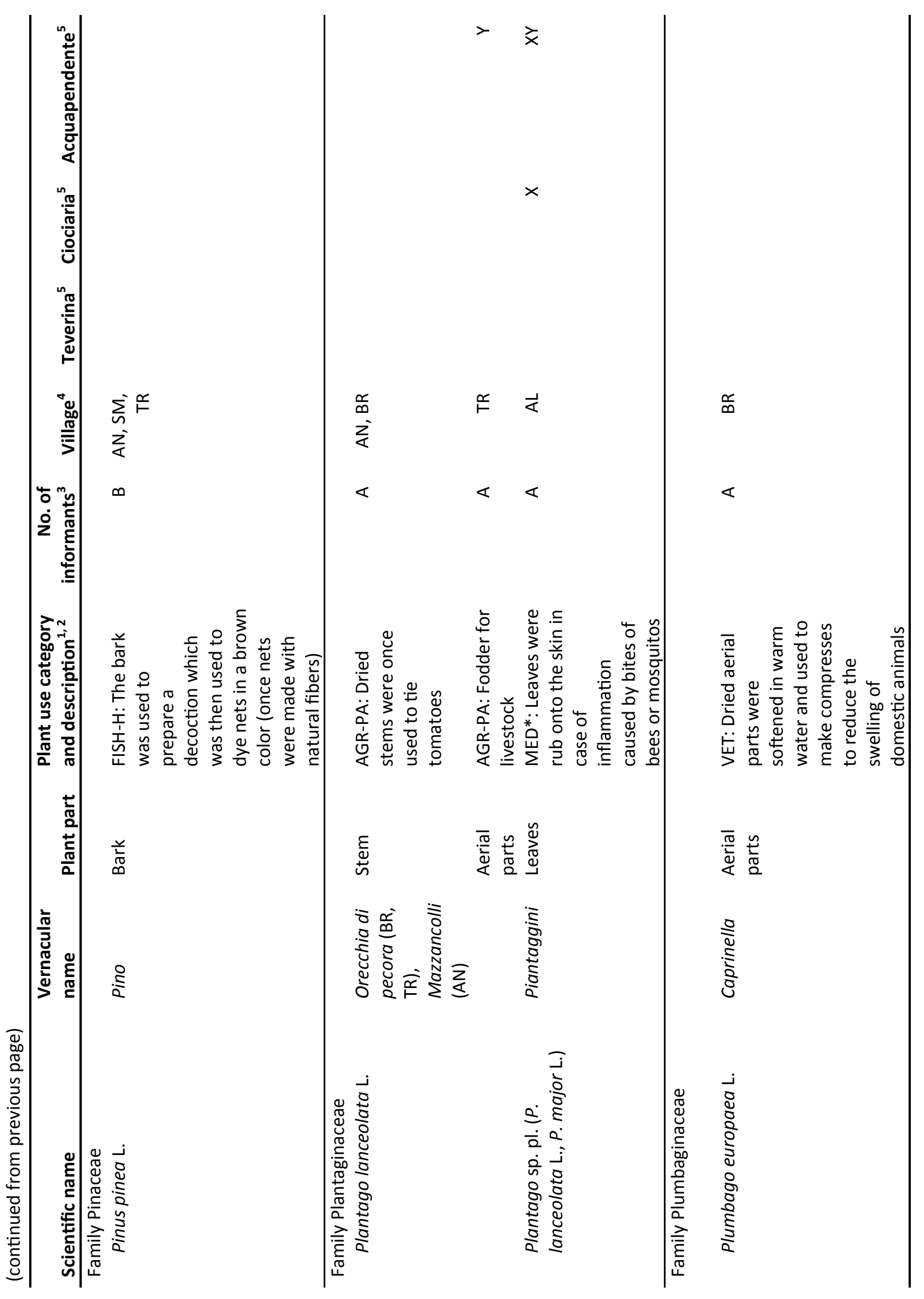




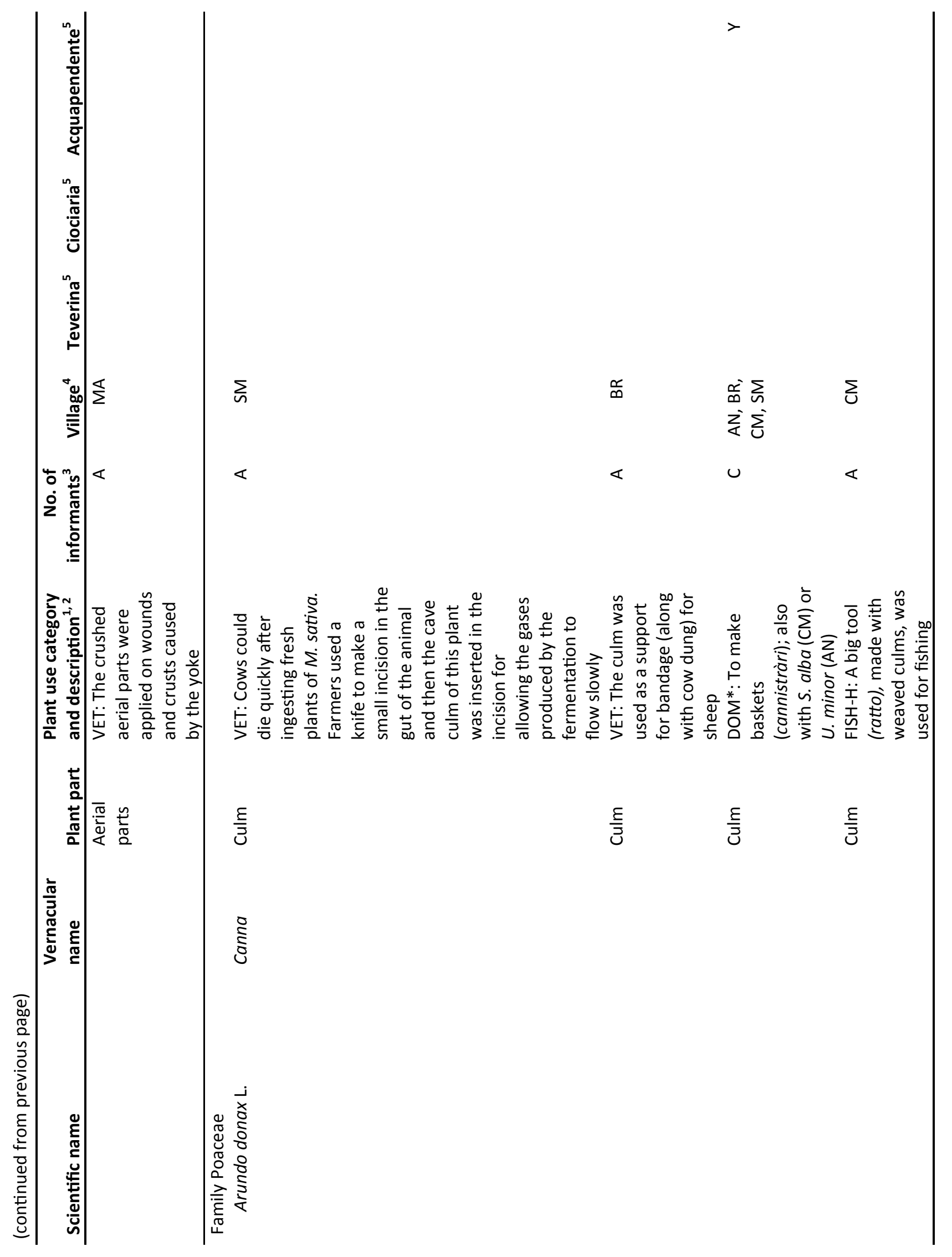

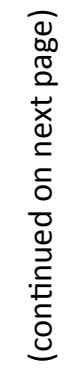




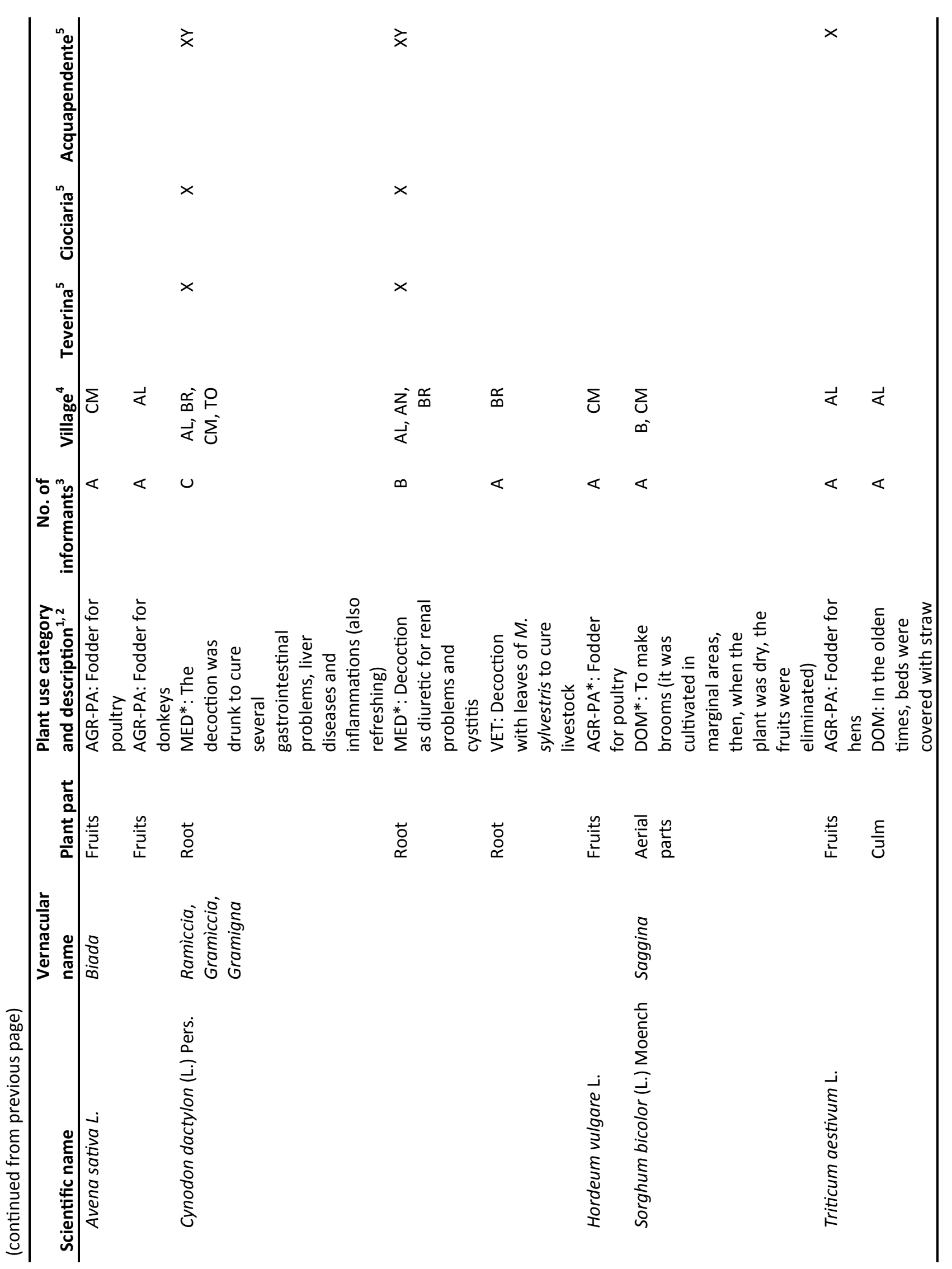






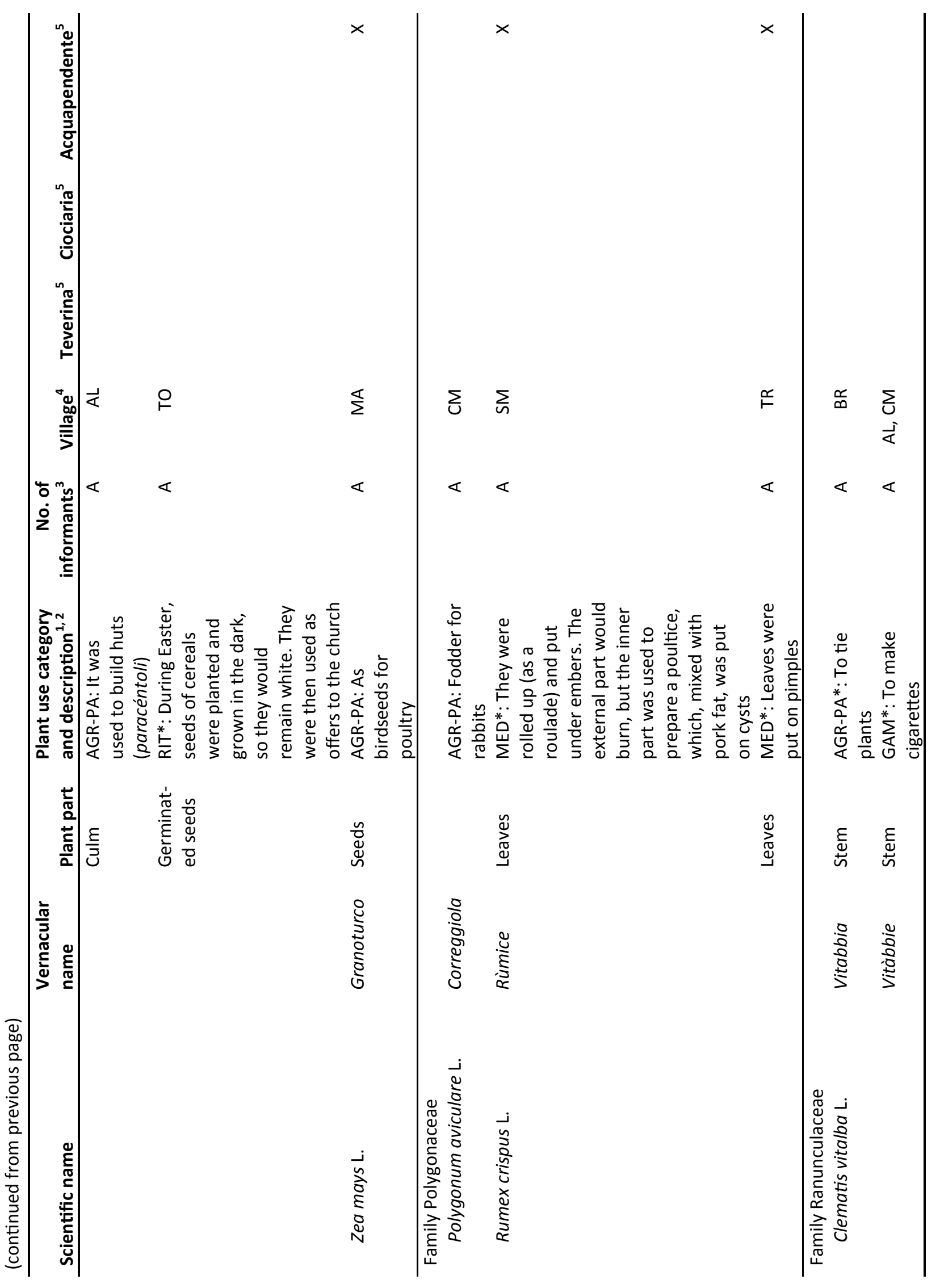



Ethnobiology Letters. 2015. 6(1):119-161. DOI: 10.14237/ebl.6.1.2015.288. 
ETHNOBIOLOGY LetTers Research Communication

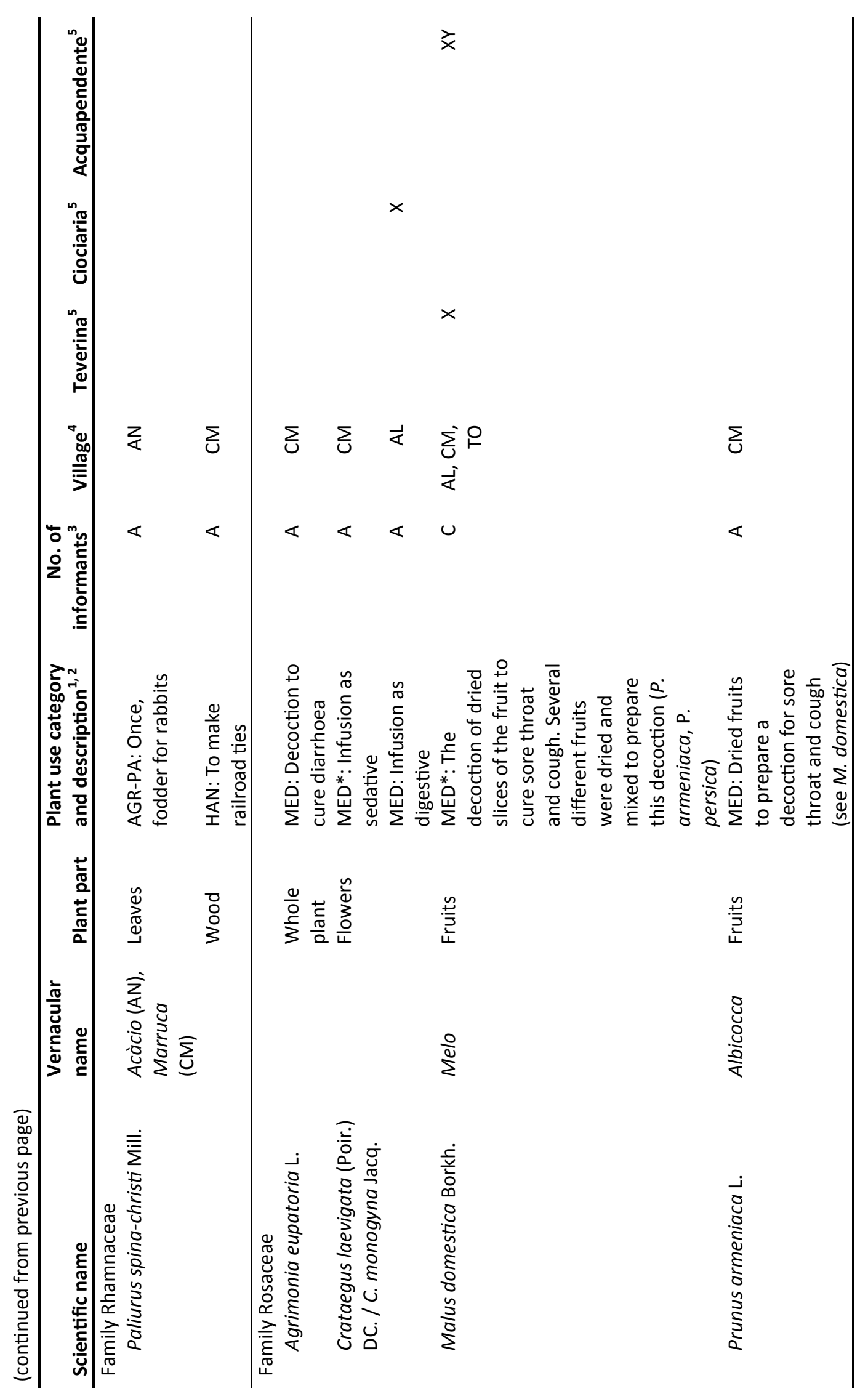




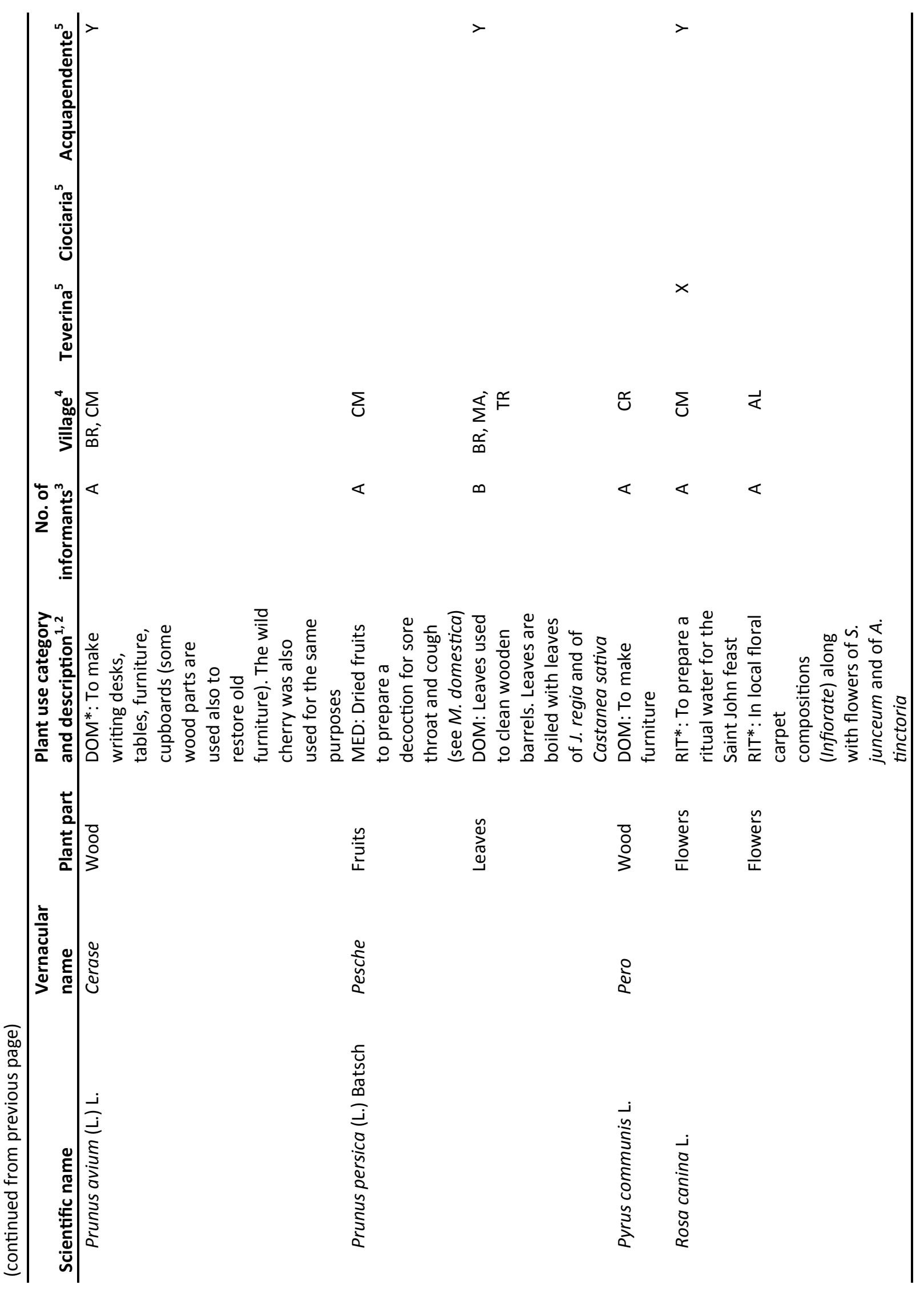






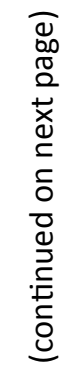




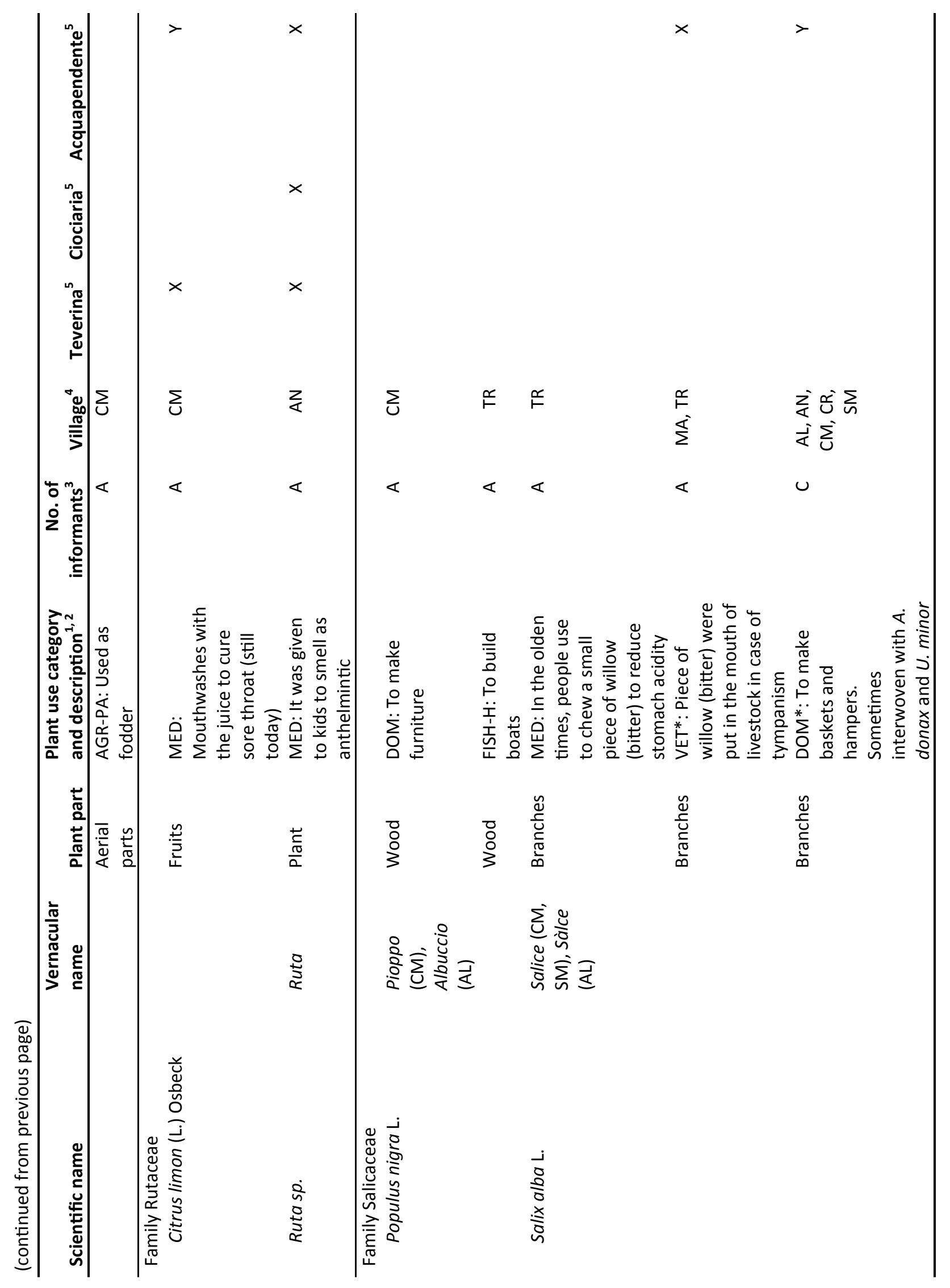


Ef Ethnobiology LetTers Research Communication

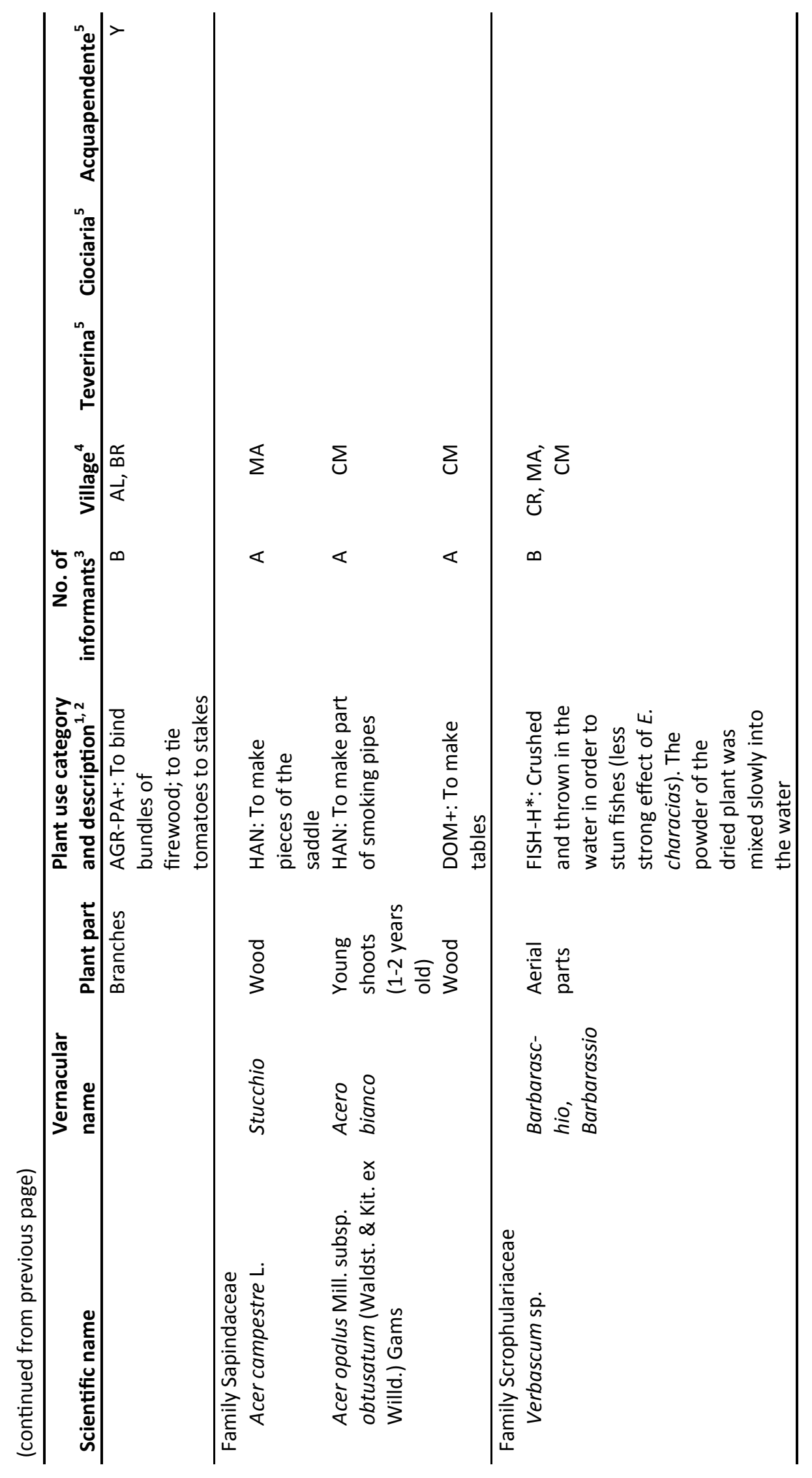




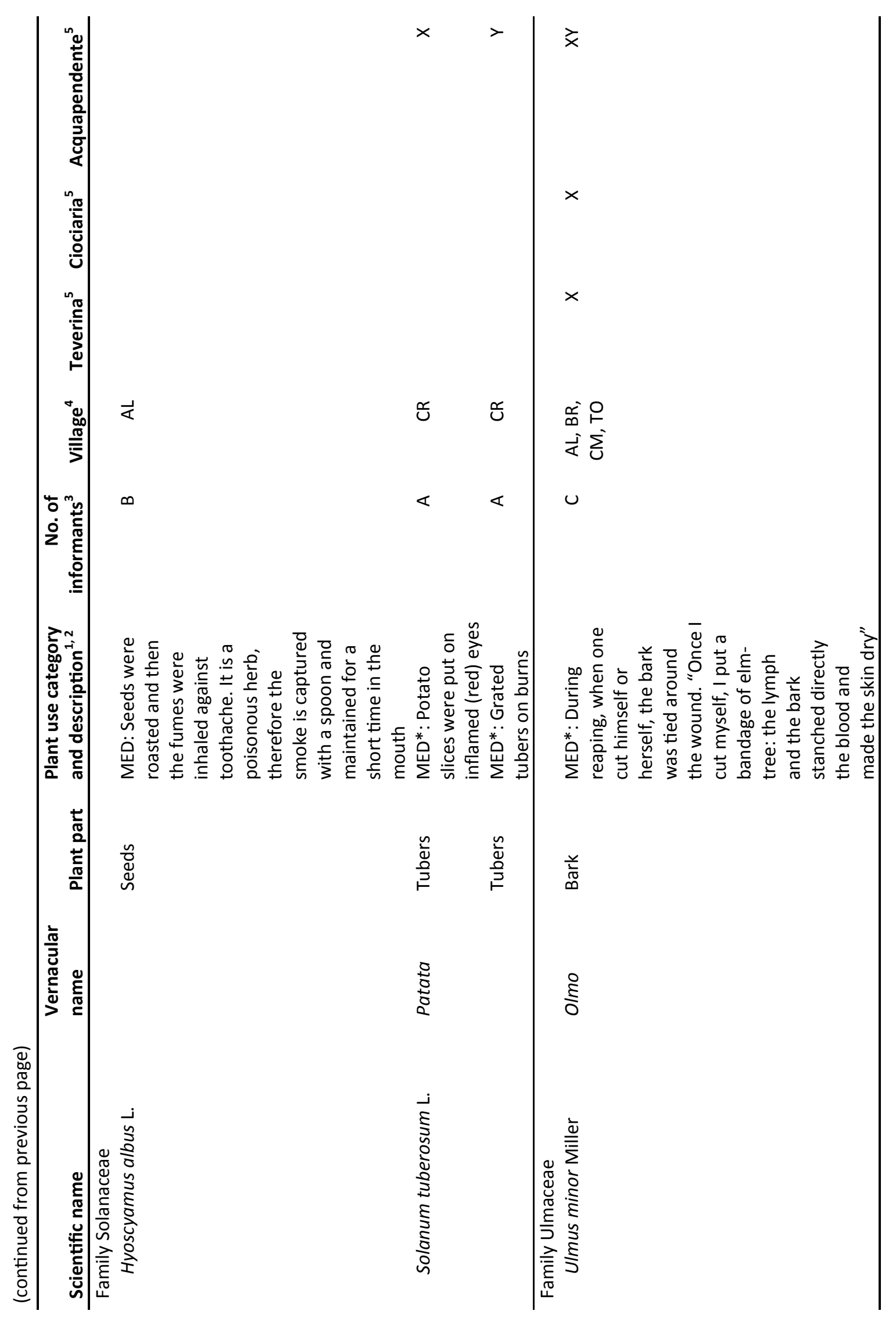




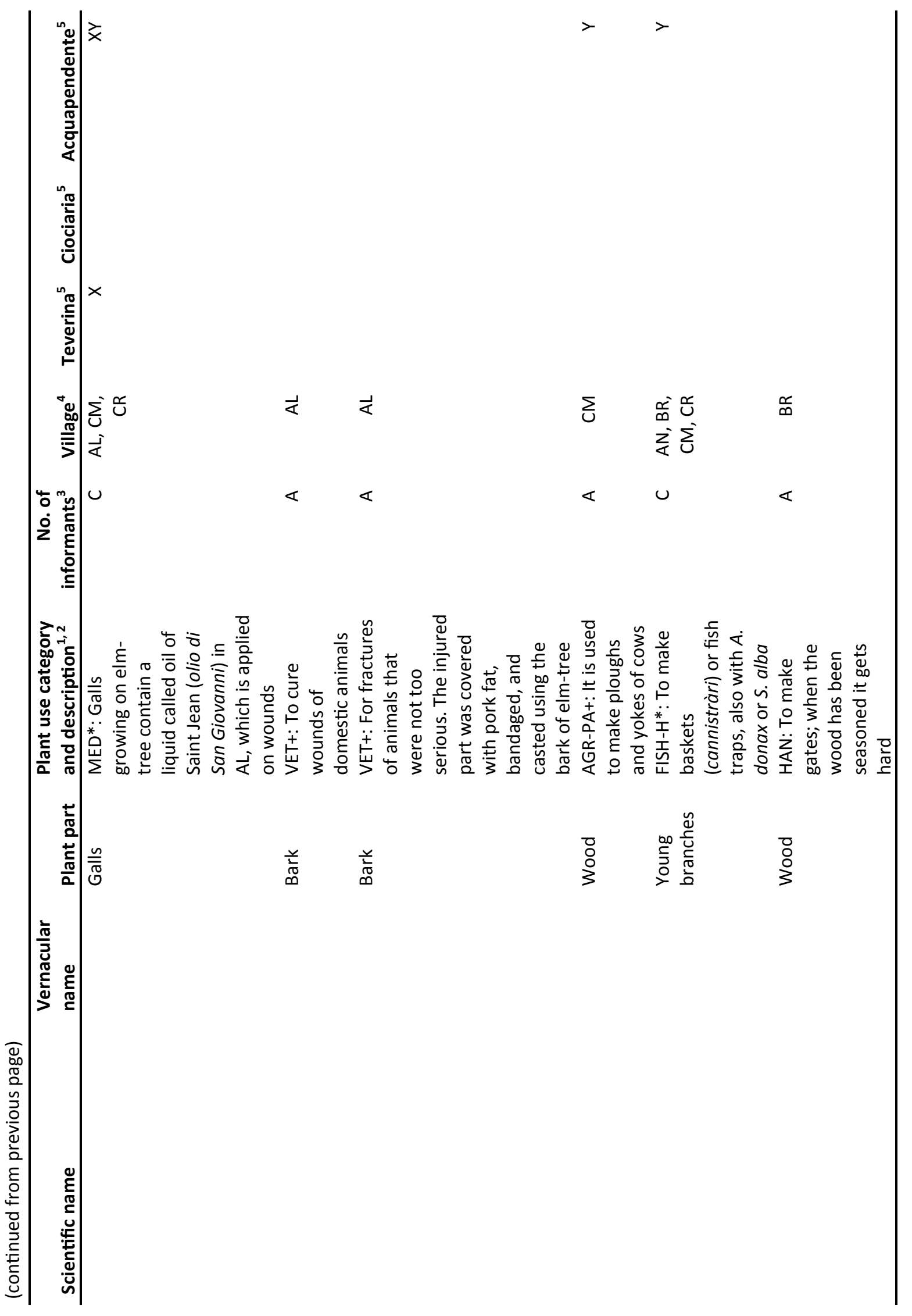




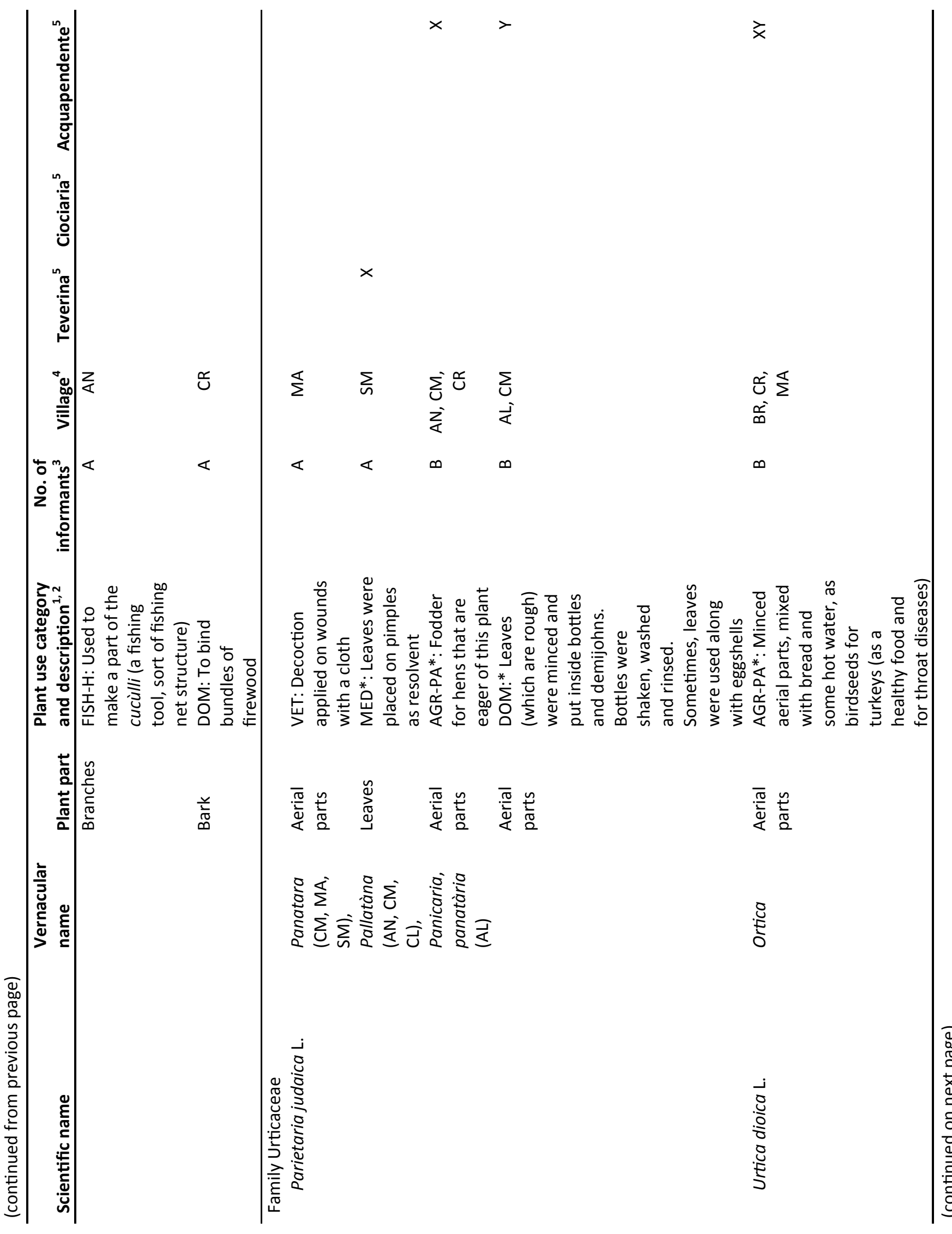


(f) Ethnobiology Letters research Communication

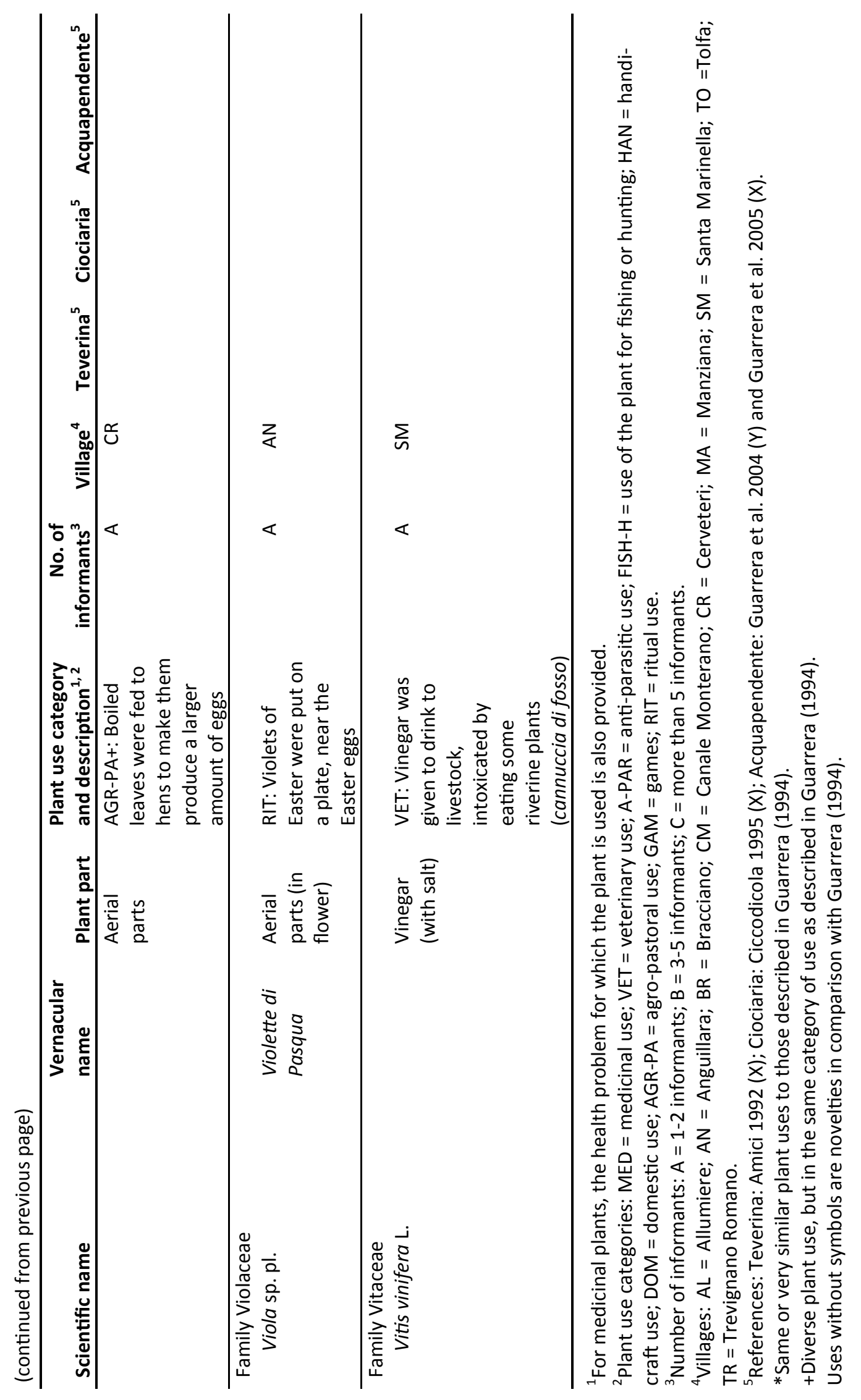

Ethnobiology Letters. 2015. 6(1):119-161. DOI: 10.14237/ebl.6.1.2015.288. 
Table 2. Uses of plants in each category, with details on their novelty or similarity to other studies.

\begin{tabular}{|c|c|c|c|c|c|}
\hline Category of plant use & $\begin{array}{r}\text { Number of } \\
\text { species }\end{array}$ & $\begin{array}{r}\text { Number of plant } \\
\text { uses }\end{array}$ & $\begin{array}{r}\text { New plant } \\
\text { uses }^{1}\end{array}$ & $\begin{array}{r}\begin{array}{r}\text { Similar plant } \\
\text { uses }^{2}\end{array} \\
\end{array}$ & $\begin{array}{r}\text { Alternative plant } \\
\text { uses }^{3}\end{array}$ \\
\hline Human medicine & 33 & 60 & 23 & 33 & 4 \\
\hline Veterinary medicine & 16 & 19 & 12 & 5 & 2 \\
\hline Anti-parasitic & 2 & 2 & 0 & 2 & 0 \\
\hline Agro-pastoral & 42 & 46 & 30 & 10 & 6 \\
\hline Handicrafts & 14 & 20 & 14 & 3 & 3 \\
\hline Domestic & 34 & 52 & 25 & 18 & 9 \\
\hline Fishery or hunting & 11 & 15 & 9 & 4 & 2 \\
\hline Games & 8 & 8 & 4 & 3 & 1 \\
\hline Rituals & 14 & 17 & 8 & 8 & 1 \\
\hline
\end{tabular}

${ }^{1}$ New plant uses that have not been reported before for the area.

${ }^{2}$ Similar or same plant uses as reported in literature.

${ }^{3}$ Alternative plant uses that are different but in the same use category.

and skin lesions in Guarrera (1994). Plant uses recorded in this study were also compared to those reported in other case studies conducted in the Latium region (Guarrera 2006 and references therein) in order to identify points of convergence and to evaluate differences in the local ethnobotanical knowledge. These comparisons were not quantitative considering that previous studies were conducted with different research methods (including distinctive foci of specific plant uses), study times, and geographic research areas (Mustafa et al. 2012).

\section{Results}

According to our survey, the ethnobotanical knowledge of the Tolfa-Cerite-Manziate area comprises the use of 102 plant species (Table 1). In Table 1, the names of the species are reported along with their vernacular names, plant parts, category of use, number of citations and the locality where the plant is used. Moreover, we report the detailed explanation of the most recent plant uses along with a comparison with plant uses reported in other studies of the Latium region, including that by Guarrera (1994). Species belong to 48 families, the majority of families (28) include only one species, while Rosaceae (12 species) and Poaceae (eight species) are prominently represented families.

Many plants have more than one use within and across categories. Several plants have similar uses in other areas of the Latium region, while some plants and their uses have not been previously reported in those areas. The locality that shares the highest number (74) of plant uses is that of Acquapendente (Guarrera et al. 2004, 2005). In our survey, we recorded a total of 239 different plant uses, among which many (125) have not reported before for the area, some (86) are similar to the same use as reported in literature, several (28) are different but in the same usage category (Table 2). The ten non-plant based remedies are reported in Table 3. A total of six remedies are used in veterinary medicine and six in human medicine.

Many previously-recorded plant uses are no longer practiced or are no longer common in the memories of individuals in the local communities. Plants and remedies that are no longer used include: Barbarea vulgaris R. Br. Brassicaceae for cough, Dittrichia viscosa (L.) Greuter Asteraceae for haemorrhoids, or Phillyrea latifolia L. Oleaceae for toothache (Guarrera 1994). Today, the plants mentioned for toothache are P. lentiscus (a similar use is known for Vallecorsa, Southern Latium), E. characias, M. sylvestris and $H$. albus (the last three uses were also reported by Guarrera 1994).

In some cases, a specific medicinal use is no longer practiced because the disease is no longer present. For example, malaria has been locally eradicated and the antimalarial decoction of 100 cloves of garlic (A. sativum) in a liter of vinegar ( $V$. vinifera) is no longer remembered or used. In other cases, plants are used less frequently because of reduced availability on the landscape. Informants mention that, in the past, $M$. chamomilla was abundant in local meadows and fields but now it is difficult to find this officinal herb due to the use of herbicides.

Agro-pastoralism is important in the Tolfa-Cerite -Manziate area, and, not surprisingly, veterinary uses 
Table 3. Non-plant based uses (mostly remedies in human and veterinary medicine).

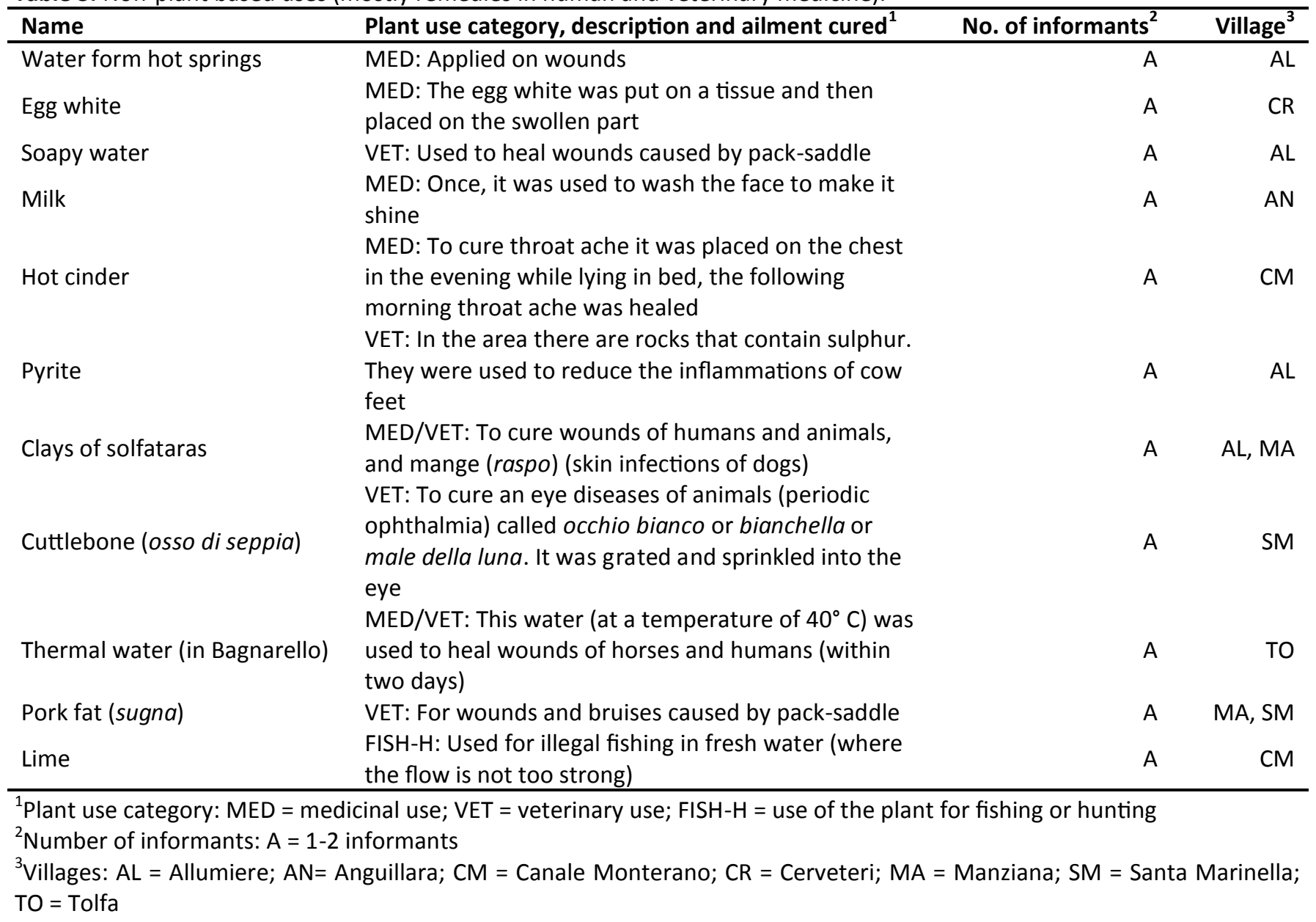

of plants are vivid in the memories of local community members. Some veterinary remedies seem to be unique to the area when compared with bibliographic data from Guarrera (2006). Examples include the ancient use of $S$.junceum for castrating bulls and the use of P. europaea (caprinella) to cure the swelling in domestic animals. Although the practice of feeding cows with $R$. peregrina for expelling the seconda (placenta) has been previously mentioned in Guarrera (1994), it is known only in the Tolfa - Allumiere area (Guarrera 2006).

Some plants are used to feed livestock to improve their health as a sort of veterinary nutraceutical. $C$. arvensis along with several herbs of the Fabaceae family are used to feed cows for their galactagogue properties. Local farmers of the area believe that feeding poultry with $S$. minor subsp. balearica, but also $U$. dioica, could increase egg production. Additionally, if hens were making soft eggshell, some rubble
(Canale Monterano) or eggshell (Allumiere) were mixed with fodder.

Anti-parasitic uses are very few. Only two plants, C. nepeta and L. angustifolia, are mentioned by the informants. These two plants, like other Lamiaceae, are aromatic and thus have repellent properties (Guarrera 1999). On the other hand, the use of Artemisia absinthium L. Asteraceae as a repellent for cows, horses and other animals (Guarrera 1994) is no longer remembered.

Local inhabitants were used to diversify their diets with some fish caught in marshes, ditches, or the Bracciano Lake. Some fishing practices - now illegal entailed the use of plants for narcotizing fish in small water basins (E. characias and Verbascum species). Several species of the genus Euphorbia and Verbascum are used for the same purpose in many other Italian areas (Guarrera 2006). Local people also used lime (Canale Monterano) for catching fish. 
Many plants were used while working in the fields or at home. Some plant uses are already known for other Italian regions (e.g., the use of $S$. alba or $S$. junceum for tying vines [the name Spartium comes from the Greek $\Sigma \pi a \varrho \tau o v=$ rope]). E. arborea, used to make smoking pipes and other objects, is locally named brugo, which is the vernacular name of another plant of the Ericaceae family [Calluna vulgaris (L.) Hull Ericaceae] that does not grow locally. However, E. arborea is also called scopa marina (marine broom), because it is used to make brooms. Another way to connect a plant to a use in the area was the creation of proverbs like: "L'ornello fa il fuoco bello" (Anguillara) which means "The manna-ash tree (F. ormus) makes a beautiful fire" because the plant is used as firewood.

Many species are widely used either because they are common or have special technical properties. The invasive species R. pseudacacia, the common Castanea sativa or Quercus sp. pl. are among the species with the highest number of domestic uses as well as the rare $F$. sylvatica. These species are mainly used for their wood.

Some plant uses that have never been reported in the ethnobiological literature are potentially unique to the area, such as those of C. australis or of B. pendula. C. australis is widely used and appreciated in the area for its strength and flexibility, but it is rarely used in other Italian regions even though it has a large distribution. This plant also has many different names in the area, some of which are new according to the ethno-linguistic work by Penzig (1924). In contrast, $B$. pendula is a rare species that has a limited distribution in Italy.

In some cases it was possible to highlight, in a direct way, a potential loss of information. Saponaria officinalis L. Caryophyllaceae was widely used all over Italy to do laundry (Guarrera 2006). This plant grows everywhere in the area but was never mentioned by informants even if it was present during the interviews. This could indicate a loss of knowledge or eventually an absence of use, since some informants reported the practice of making soap from cinder and pork fat. Another potential loss of a use is that of $P$. aviculare (correggiola): the name comes from the correggioli, which are the leather strips or laces to bind the shoes, but this use was not mentioned during our interviews.

The report of plants used for games is very rare for the area but also for Italy (Guarrera 2006). Castanea sativa was used to make a small trumpet called peta (one of these trumpets is displayed at the
Museo Nazionale delle Arti e Tradizioni Popolari in Rome). The same use of Castanea sativa is also reported for this species in northern Italy (Guarrera 2006).

In the Tolfa-Cerite-Manziate area, people preserve various ritual uses of plants (in their memories or in their current daily life). Several aromatic plants (e.g., T. balsamita, H. perforatum, J. regia) were put in water overnight (between the $23^{\text {rd }}$ and $24^{\text {th }}$ of June), and this ritual water was used to wash the face on the morning of the Saint John feast (24 June) as a substitute for the very ancient rituals of the summer solstice. Many plants are still used to make floral carpets (Infiorate) during the Corpus Christi feast but also for Easter rituals. Evil eye, bad luck and witches were kept away in different ways (e.g., with rituals using olive oil or putting a small broom of E. arborea behind the main door) together with the erba croce (probably Verbena officinalis L. Verbenaceae, as reported for Acquapendente [Guarrera et al. 2005]).

\section{Discussion}

Our investigation on the ethnobotanical knowledge of the Tolfa-Cerite-Manziate area highlighted some new interesting uses of plants but also a potential loss of this knowledge. For example, the plant uses of $C$. australis or of $B$. pendula have not been previously reported in literature. Our comparison with a previous study in the area (which had different foci of research and areas of investigation) suggested a loss of knowledge. While it is not possible to quantify this loss, our results support a decrease of knowledge about medicinal uses of plants. Considering that the study area of Guarrera (1994) was more limited than ours, the number of medicinal plants that are no longer recalled is considerable. We believe that it is still important to document ethnobotanical knowledge so it can be realized how much of this knowledge is disappearing especially in places where technology and modern lifestyles are replacing traditional practices.

Local knowledge (ethnobotanical or ecological) is part of the social memory (sensu Folke et al. 2005) of a socio-ecological system such as that of the TolfaCerite-Manziate area. The preservation of this local knowledge (and social memory) is important for sustainable management of the environment and for dealing with future socio-ecological changes (Adger et al. 2005; Johnson and Hunn 2010). In a general context of rural depopulation and local knowledge erosion, it is fundamental to define strategies to counteract these trends. Practical solutions to sustain 
rural livelihoods and foster the resilience of local knowledge in the Tolfa-Cerite-Manziate area could entail the re-evaluation of traditional practices, food preparations, and handicraft making for tourism. This could generate some revenue for local population and reduce the loss of the rich local knowledge of the area.

\section{Acknowledgments}

Voucher specimens are preserved at the Istituto Centrale per la Demoetnoantropologia (Rome). We are very grateful to the people of the Tolfa-CeriteManziate area who shared their ethnobotanical knowledge with us. Thanks are due to Yarissa MatosSoto (University of Central Florida) for helping in some field surveys. We are grateful to Francois Salomone (University of Roma Tre) for providing Figure 1. Thanks are due to Kamen MacKay for checking the English language. Many thanks are due to the Provincia di Roma and to the University Roma Tre for granting this research within the project " $L e$ specie vegetali tipiche del comprensorio Tolfetano-CeriteManziate di uso tradizionale e valutazione delle loro potenzialità economiche".

\section{Declarations}

Permissions: Prior informed consent to carry out interviews was requested verbally to each informant.

Sources of Funding: The Provincia di Roma and the University Roma Tre supported this study through the project "Le specie vegetali tipiche del comprensorio Tolfetano-Cerite-Manziate di uso tradizionale e valutazione delle loro potenzialità economiche."

Conflicts of Interest: None declared.

\section{References Cited}

Adger, W. N., T. P. Hughes, C. Folke, S. R. Carpenter and J. Rockström. 2005. Social-Ecological Resilience to Coastal Disasters. Science 309:1036-1039.

Amici, L. 1992. Medicina Popolare della Teverina. Regione Lazio Assessorato alla Cultura, Associazione Intercomunale della Teverina per la cultura. Union Printing, Viterbo, Italy.

Angelelli, F. and S. Faramondi. 1995. Lineamenti Geologici della Regione Tolfetana. Geo Archeologia 1:11-50.

Anzalone, B. 1961. Osservazioni Fitosociologiche su Alcune Faggete Depresse del Lazio. Annali di Botanica 27:120-133.
Bernard, H. R. 1988. Research Methods in Cultural Anthropology. Sage, Newbury Park, CA.

Caneva, G., A. Pieroni and P. M. Guarrera, eds. 2013. Etnobotanica. Conservazione di un Patrimonio Culturale come Risorsa per uno Sviluppo Sostenibile. Università Roma Tre (CROMA) e Centro Universitario Europeo per i Beni Culturali, Ravello. Edipuglia, Bari, Italy.

Ciccodicola, F. 1995. Pratiche di Guarigione nella Memoria Collettiva - Risultati di una Ricerca sul Campo. In Quaderni di Storia, Antropologia e Scienze del Linguaggio. Le Piante Magiche. Una Ricerca StoricoAntropologica edited by Giusti S., pp. 241-313. Domograf, Rome, Italy.

Cox, P. A. 2000. Will Tribal Knowledge Survive the Millennium? Science 287:44-45. Doi: 10.1126/ science.287.5450.44.

CRA-CMA. 2012. Banca Dati Agrometeorologica Nazionale. Available at: http://cma.entecra.it/ Banca_dati_agrometeo/index $3 . h t m$. Accessed on July 20, 2012.

Devoto, G. and G. Lombardi. 1977. Le Formazioni Sedimentarie ed Eruttive del Settore Tolfetano Cerite - Manziate (Lazio Nordoccidentale). Quaderni Accademia Nazionale dei Lincei 227:5-31.

di Tizio, A., Ł. J. Łuczaj, C. L. Quave, S. Redžić and A. Pieroni. 2012. Traditional Food and Herbal Uses of Wild Plants in the Ancient South-Slavic Diaspora of Mundimitar/Montemitro (Southern Italy). Journal of Ethnobiology and Ethnomedicine 8:21. Doi: 10.1186/1746-4269-8-21.

Di Pietro, R., M. M. Azzella and L. Facioni. 2010. The Forest Vegetation of the Tolfa - Ceriti Mountains (Northern Latium - Central Italy). Hacquetia 9:91150. Doi: 10.2478/v10028-010-0002-2.

Fanelli, G., M. Bertarelli, P. M. Bianco, V. Caroselli, P. Cazzagon, D. D'Angeli, S. De Corso, M. De Sanctis, A. Gioia, A. Guerra, A. Serafini Sauli, A. Testi and S. Pignatti. 2007. Carta della Vegetazione della Provincia di Roma. Provincia di Roma, Rome, Italy.

Folke, C., T. Hahn, P. Olsson and J. Norberg. 2005. Adaptive Governance of Social-Ecological Systems. Annual Review of Environment and Resources 30:441-473. Doi: 10.1146/annurev.energy.30.050504.144511

Guarrera, P. M. 1994. Il Patrimonio Etnobotanico del Lazio. Assessorato alla Cultura Regione Lazio and 
Dipartimento Biologia Vegetale Università "La Sapienza". Tipar, Rome, Italy.

Guarrera, P. M. 1999. Traditional Antihelmintic, Antiparasitic and Repellent Uses of Plants in Central Italy. Journal of Ethnopharmacology 68:183-192. Doi:10.1016/S0378-8741(99)00089-6.

Guarrera, P. M. 2006. Usi e Tradizioni della Flora Italiana. Medicina Popolare ed Etnobotanica. Aracne, Rome, Italy.

Guarrera, P. M., G. Forti and S. Marignoli. 2005. Ethnobotanical and Ethnomedicinal Uses of Plants in the District of Acquapendente (Latium, Central Italy). Journal of Ethnopharmacology 96:429- 444. Doi: 10.1016/j.jep.2004.09.014.

Guarrera, P. M., G. Forti, S. Marignoli and G. Gelsomini. 2004. Piante e Tradizione Popolare ad Acquapendente. Quaderni del Museo del Fiore n.2. Comune di Acquapendente, Regione Lazio, Acquapendente, Italy.

ISE. 2006. International Society of Ethnobiology Code of Ethics (with 2008 additions). Available at: www.ethnobiology.net/ethics.php. Accessed on September 10, 2014.

Johnson, L. M. and E. S. Hunn, eds. 2010. Landscape Ethnoecology: Concepts of Biotic and Physical Space.

Berghahn Books, New York, USA.

Leonti, M., L. Casu, F. Sanna and L. Bonsignore. 2009. A Comparison of Medicinal Plant Use in Sardinia and Sicily_De Materia Medica Revisited? Journal of Ethnopharmacology 121:255-267. Doi: 10.1016/j.jep.2008.10.027.

Mustafa, B., A. Hajdari, F. Krasniqi, E. Hoxha, H. Ademi, C. L. Quave and A. Pieroni. 2012. Medical Ethnobotany of the Albanian Alps in Kosovo. Journal of Ethnobiology and Ethnomedicine 8:6. Doi: 10.1186/1746-4269-8-6.

Pardo-de-Santayana, M., A. Pieroni and R. Puri. 2010. The Ethnobotany of Europe, Past and Present. In Ethnobotany in the New Europe: People, Health and Wild Plant Resources, edited by Pardo-de-Santayana, M., A. Pieroni and R. Puri, pp. 1-15. Berghahn Books, New York, USA.

Penzig, O. 1924. Flora Popolare Italiana, vol. 1-2. Tipolitografia Regio Istituto Sordomuti, Genova, Italy.
Pieroni, A., B. Rexhepi, A. Nedelcheva, A Hajdari, B. Mustafa, V. Kolosova, K. Cianfaglione and C. L. Quave. 2013. One Century Later: the Folk Botanical Knowledge of the Last Remaining Albanians of the Upper Reka Valley, Mount Korab, Western Macedonia. Journal of Ethnobiology and Ethnomedicine 9:22. Doi: 10.1186/1746-4269-9-22.

Pignatti, S. 1982. Flora d'Italia, vol.1-3. Edagricole, Bologna, Italy.

Rosenthal, J. P. 2006. Politics, Culture, and Governance in the Development of Prior Informed Consent in Indigenous Communities. Current Anthropology 47:119-142. Doi: 10.1086/497670.

Salvati, L. and A. Sabbi. 2011. Exploring Long-Term Land Cover Changes in an Urban Region of Southern Europe. International Journal of Sustainable Development \& World Ecology 18:273-282. Doi: 10.1080/13504509.2011.560453.

Savo, V., E. De Zuliani, L. Salvati, L. Perini and G. Caneva. 2012. Long-Term Changes in Precipitation and Temperature Patterns and their Possible Impacts on Vegetation (Tolfa - Cerite Area, Central Italy). Applied Ecology and Environmental Research 10:243-266. Available at: http://www.ecology.unicorvinus.hu/pdf/1003_243266.pdf. Accessed on: September 10, 2014.

Signorini, M. A., P. Bruschi, F. Camangi, P. M. Guarrera, A. Pieroni and V. Savo. 2013. Metodi della Ricerca Etnobotanica. In Etnobotanica, Conservazione di un Patrimonio Culturale Immateriale come Risorsa per uno Sviluppo Sostenibile, edited by Caneva, G, A. Pieroni and P. M. Guarrera, pp. 43-68. EdiPuglia, Bari.

Spada, F. 1977. Primi Lineamenti della Vegetazione del Comprensorio Tolfetano - Cerite. - Quaderni Accademia Narionale dei Lincei 227:33-50.

ThePlantList. 2014. A Working List of All Plant Species. Available at: www.theplantlist.org. Accessed on September 10, 2014.

Vander Poppen, R. E. 2008. Rural Change and Continuity in Etruria: A Study of Village Communities from the 7 th Century BC to the 1 st Century $A D$. ProQuest, Ann Arbor, MI. 


\section{Biosketches}

Paolo Maria Guarrera is a biologist at the Istituto Centrale per la Demoetnoantropologia. His research interests include ethnobotany and ethnomedicine.

Valentina Savo is a postdoctoral researcher at Simon Fraser University. Her research focuses on humanenvironment relationships (ethnobotany, TEK, environmental changes).
Giulia Caneva is a full professor at University Roma Tre. Her research interests include ethnobotany, Mediterranean vegetation, and cultural heritage protection.

\section{Notes}

${ }^{1}$ http://eur-lex.europa.eu/legal-content/EN/TXT/ P D F / ? u ri = CE LE X:0 1992 L 0043 20070101\&from $=\mathrm{EN}$ 